\title{
Structure and evolution of the Carpathian thrust front between Tarnów and Pilzno (Pogórska Wola area, southern Poland) - results of integrated analysis of seismic and borehole data
}

\author{
Piotr KRZYWIEC ${ }^{1, *}$, Nestor OSZCZYPKO ${ }^{2}$, Krzysztof BUKOWSKI ${ }^{3}$, Marta OSZCZYPKO-CLOWES ${ }^{2}$, \\ Michał ŚMIGIELSKI ${ }^{4}$, Finlay M. STUART ${ }^{5}$, Cristina PERSANO ${ }^{6}$ and Hugh D. SINCLAIR ${ }^{7}$ \\ 1 Polish Academy of Sciences, Institute of Geological Sciences, Twarda 51/55, 00-818 Warszawa, Poland \\ 2 Jagiellonian University, Institute of Geological Sciences, Oleandry 2A, 30-063 Kraków, Poland \\ 3 AGH University of Science and Technology, Faculty of Geology, Geophysics and Environmental Protection, \\ Al. A. Mickiewicza 30, 30-059 Kraków, Poland \\ 4 Mickiewicza 2/2, 05-820 Piastów, Poland \\ 5 Scottish Universities Environmental Research Centre, Rankine Avenue, Scottish Enterprise Technology Park, East \\ Kilbride, G75 OQF, Scotland, United Kingdom \\ 6 University of Glasgow, School of Geographical and Earth Sciences, Gregory Building, Glasgow, G12 8QQ, United Kingdom \\ 7 University of Edinburgh, School of GeoSciences, Drummond Street, Edinburgh EH8 9XP, United Kingdom
}

Krzywiec, P., Oszczypko, N., Bukowski, K., Oszczypko-Clowes, M., Śmigielski, M., Stuart, F.M., Persano, C., Sinclair, H.D., 2014. Structure and evolution of the Carpathian thrust front between Tarnów and Pilzno (Pogórska Wola area, southern Poland) - results of integrated analysis of seismic and borehole data. Geological Quarterly, 58 (3): 409-426, doi: 10.7306/gq. 1189

Seismic data and core from the shallow cartographic Pilzno P-7 borehole were used to construct a new model of the Carpathian orogenic front between Tarnów and Pilzno, in the Pogórska Wola area (southern Poland). The most external, frontal thrust of the orogenic wedge (the Jaśniny structure) was identified as a syn-depositional fault-propagation fold detached above the Upper Badenian evaporites. Its formation was controlled by the presence of mechanically weak foredeep evaporites and by the morphology of the sub-Miocene Meso-Paleozoic foreland plate (Jaśniny and Pogórska Wola palaeovalleys). The frontal zone of the Carpathian orogenic wedge (the Skole thrust sheet and the deformed foredeep deposits of the Zgłobice thrust sheet) is characterized by significant backthrusting of the foredeep succession towards the south, and by the presence of a triangle zone, with strongly deformed Upper Badenian evaporites of the Wieliczka Formation in its core. The triangle zone was formed during the latest thrusting movements of the Carpathians. An indication of the existence of the triangle zone in the vicinity of Dębica has also been provided by reinterpretation of the archive regional geological cross-section. The youngest foredeep deposits, brought to the surface above the backthrust, have been dated as Sarmatian (NN7 nannoplankton zone), which indicates that the latest thrust movements within the frontal Carpathian orogenic in the vicinity of Tarnów-Dębica took place approx. 11-10 million years ago. Thermochronological studies (AFT and $\mathrm{AHe}$ ) indicated that the foredeep succession drilled by the Pilzno P-7 borehole has not been buried deeper than $1.5-2 \mathrm{~km}$, which is compatible with reconstruction based on the seismic data.

Key words: Carpathians, Carpathian Foredeep Basin, Pilzno embayment, Miocene, evaporites, wedge tectonics.

\section{INTRODUCTION}

The Outer Carpathians in Poland were thrust over the foreland plate in late Early/Middle Miocene times (see e.g. Nemčok et al., 2006; Ślączka et al., 2006; Gagała et al., 2012 for detailed overviews and further references). The Carpathian Foredeep Basin developed in front of the advancing Carpathian thrust belt

*Corresponding author: piotr.krzywiec@twarda.pan.pl

Received: June 23, 2014; accepted: August 25, 2014; first published online: September 2, 2014
(Oszczypko, 1998; Oszczypko et al., 2006; Oszczypko and Oszczypko-Clowes, 2012). Its most external, relatively undeformed part is located to the north of the Outer Carpathian thrust sheets. More southern parts of the basin have been either overridden by the Carpathians or incorporated into the orogenic belt and presently forms a relatively narrow (maximum of a few kilometres) zone of deformed Miocene foredeep deposits, the so-called Zgłobice Unit or thrust sheet (Fig. 1; Kotlarczyk, 1985; cf. Oszczypko et al., 2006).

The early Miocene sea of the Carpathian Foredeep Basin covered a Meso-Paleozoic foreland platform and encroached onto the Outer Carpathian thrust sheets in the south. During the development of this sedimentary basin in Badenian-Sarmatian 


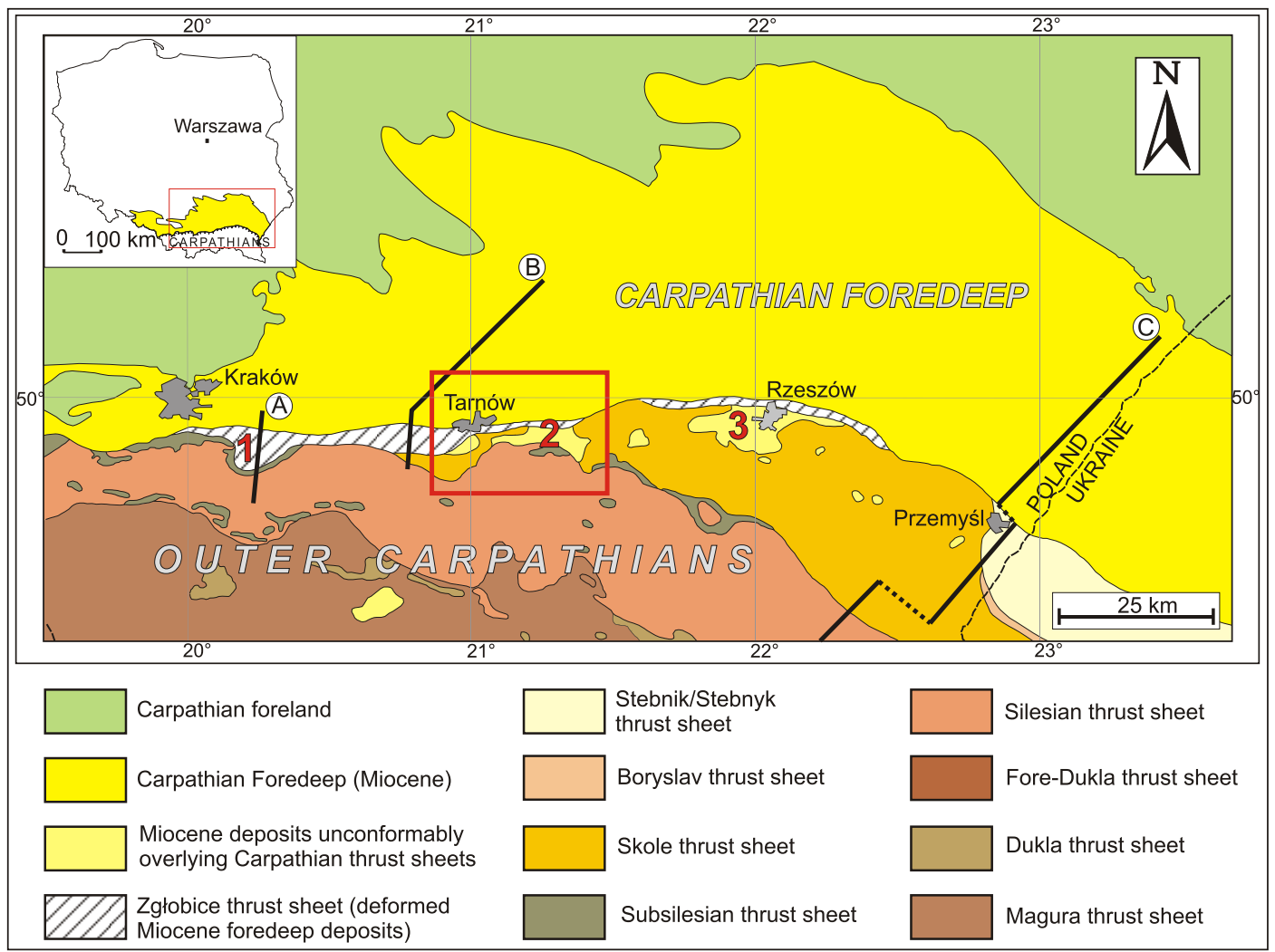

Fig. 1. Simplified geological map of the Outer Carpathians and their foreland between Kraków and Przemyśl

Red rectangle - area shown on Figure 3; 1 - Gdów embayment, 2 - Pilzno embayment, 3 - Rzeszów embayment; A - seismo-geological transect analysed in Krzywiec et al. (2012); B - seismo-geological transect analysed in Krzywiec and Vergés (2007); C - northern part of the regional geological transect analysed in Gagała et al. (2012)

times (Fig. 2), marine sedimentation prevailed. The Late Badenian salinity crisis was associated with deposition of an extensive cover of evaporites (rock salt and gypsum) which marked a significant shallowing of the basin (Oszczypko et al., 2006; Peryt, 2006).

Along the orogenic front there are three areas, so-called embayments, the Gdów embayment, the Pilzno embayment and the Rzeszów embayment (Fig. 1). The Gdów embayment is filled by the sub-evaporitic deposits of the Skawina Formation (Bukowski et al., 2010; Krzywiec et al., 2012; see also below), while two other embayments are characterized by mostly supra-evaporitic foredeep deposits located above the frontal Outer Carpathian thrust sheets in a piggy-back position. Detailed analysis of the structure and tectonic evolution of the Gdów embayment has been recently presented by Krzywiec et al. (2012). Here, we present a new model for the frontal Carpathian orogenic wedge located between Tarnów and Pilzno, partly within the Pilzno embayment (Pogórska Wola area). It was constructed using primarily results of seismic data interpretation and of sedimentological, micropalaeontological and thermochronological studies of core from the shallow Pilzno P-7 borehole drilled within the frontal zone of the orogenic wedge (Fig. 3). Additional information was provided by selected archive deep boreholes drilled in this area. The model for the Pogórska Wola area was constructed primarily to better understand the Miocene evolution of the frontal Carpathian fold-and-thrust belt. It provides also impor- tant information on the role ductile evaporites and the morphology of the top of the foreland (lower) plate play during evolution of the frontal parts of the orogenic wedges.

\section{REGIONAL GEOLOGICAL BACKGROUND}

Middle Miocene times began with the extensive Early Badenian marine transgression. In the Early Badenian the axial part of the basin reached upper bathyal depths, while the northern and southern parts of the basin were within the neritic-littoral zone (cf. Oszczypko et al., 2006). The next stage of evolution of the Carpathian Foredeep Basin was associated with formation of the extensive evaporitic basin (Peryt, 2006). Shallow parts of the basin were dominated primarily by sulphate and sub-ordinarily by carbonate-littoral facies (e.g., Kasprzyk, 1993, 1999; Peryt, 1996; Peryt et al., 1997; Bąbel, 1999, 2004; Jasionowski and Peryt, 2010). Deeper parts of the basin, located along the Carpathian front, were characterized by chloride-sulphate facies - rock salts of the Wieliczka Formation (Fig. 2; see Garlicki, 1979; Peryt, 2006) that change laterally into anhydrite deposits (Garlicki, 1979) consisting of laminated anhydrite with breccia intercalations (Kasprzyk and Orti, 1998; Peryt et al., 1998). According to Babel (2004), the gypsum sub-basin was very shallow, up to several metres deep, whilst the depth of the halite sub-basin was not less than $30-40 \mathrm{~m}$. 


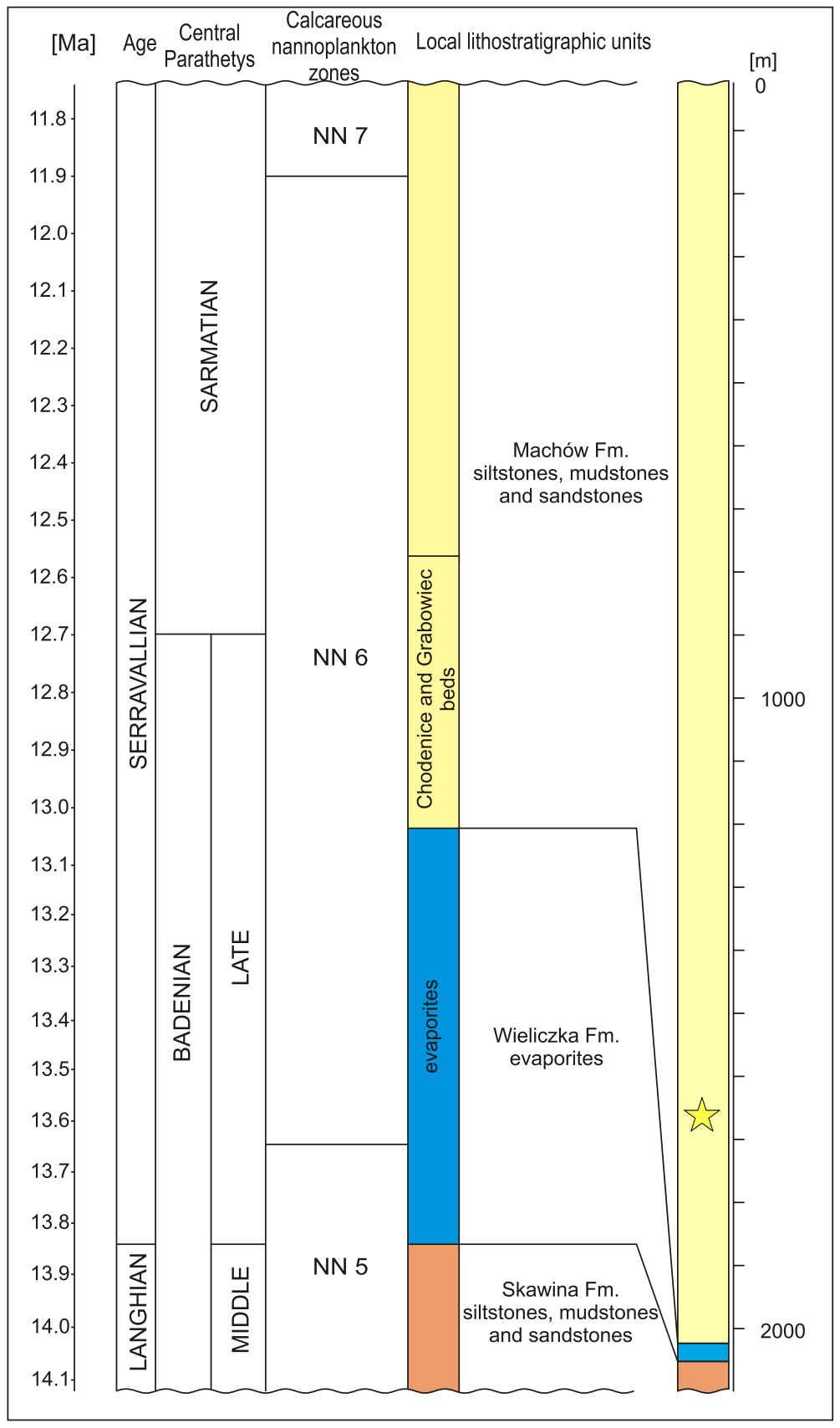

Fig. 2. Stratigraphy of the Miocene deposits of the Polish Carpathian Foredeep Basin (from Oszczypko and Oszczypko-Clowes, 2012, simplified and supplemented)

Colours used to depict local lithostratigraphic units match those used on Figures 9, 10 and 12; right column illustrates general thickness relationship of the main lithostratigraphic units of the central Carpathian Foredeep Basin in Poland (cf. Oszczypko et al., 2006); yellow star - approximate (conceptual) position of section drilled by the Pilzno P-7 borehole (cf. Figs. 10 and 12)

After the Badenian salinity crisis, the edge of the Carpathian thrust belt moved by a few kilometres to the north (see Oszczypko, 1997, 1998; Kovač et al., 1998; Oszczypko et al., 2006). These final tectonic movements resulted in migration of the zone of maximum subsidence towards the north and consequently in the progressive deepening of the outer (northern) part of the basin, which, during the deposition of the Chodenice Beds, reached depths characteristic of the outer shelf (Gonera, 1994; Kovač et al., 1998; Oszczypko, 1999).

Frontal compressional deformations of the orogenic wedge that involved foredeep deposits developed partly during deposi- tion of the supra-evaporitic Machów Formation i.e. of the Chodenice and, primarily, of the Grabowiec Beds (Fig. 2; cf. Krzywiec, 2001; Krzywiec et al., 2004; Oszczypko et al., 2006). At the same time, high sea level caused extensive marine transgression onto the Outer Carpathian thrust sheets (Oszczypko et al., 1992; Oszczypko-Clowes et al., 2009). In Sarmatian times the zone of maximum subsidence within the Carpathian Foredeep Basin migrated ca. $40-50 \mathrm{~km}$ towards the NE, towards the Teisseyre-Tornquist Zone that had been reactivated due to the foreland flexural extension accompanied by strike-slip movements (cf. Krzywiec, 2001; Krzywiec et al., 2005; Oszczypko et al., 2006; Gagała et al., 2012).

The front of the Carpathian orogenic wedge in Poland was first studied in the area located immediately south of Kraków, where rock salt has been mined for centuries in the Wieliczka and Bochnia salt mines (e.g., Schober, 1750; Townson, 1797; Pusch, 1824; Hrdina and Hrdina, 1842; Niedźwiedzki, 1883-1886; Uhlig, 1903; cf. Poborski, 1965; d'Obyrn and Przybyło, 2010). General knowledge regarding the structure of the Carpathian front significantly increased in the 20th century, due to intense exploration for rock salt and for hydrocarbons. During the following decades of intense geological and geophysical studies numerous structural models were proposed for the frontal Carpathians (see Oszczypko et al., 2006 for detailed overview and further references).

The Carpathian front was first interpreted in terms of wedge tectonics by Jones (1997). Subsequently, a model of wedge tectonics and triangle zones was used to explain the structure of the Carpathian orogenic wedge in the Wojnicz-Tarnów area (Krzywiec et al., 2004), in vicinity the of Wieliczka (Krzywiec and Vergés, 2007) and in front of the Gdów embayment (Bukowski et al., 2010; Krzywiec et al., 2012).

\section{MIOCENE EVAPORITES OF THE CARPATHIAN FOREDEEP}

Miocene evaporites are known from almost the entire Carpathian Foredeep Basin (Ney et al., 1974; Połtowicz, 1993; Peryt, 2006; Oszczypko et al., 2006). They can be found both in an autochthonous position (either in front the of the present-day thrust front or beneath the orogenic wedge) as well as in an allochthonous position within the Zgłobice thrust sheet (Garlicki, 1979; Oszczypko et al., 2006).

Owing to their lithological characteristics and widespread distribution, evaporites constitute the main correlation level in the entire foredeep basin. They are developed as two formations (Alexandrowicz et al., 1982):

- the Wieliczka Formation (chloride facies): rock salt, containing admixtures of anhydrite and gypsum, with sheet siliciclastic deposits: siltstones, mudstones and sporadically sandstones. The Wieliczka Formation is characterized by variable thickness from 30 to more than $100 \mathrm{~m}$ (Garlicki, 1979);

- the Krzyżanowice Formation (sulphate facies): developed as gypsum and anhydrite, with admixtures of siliciclastic deposits, mostly siltstones and mudstones, as 


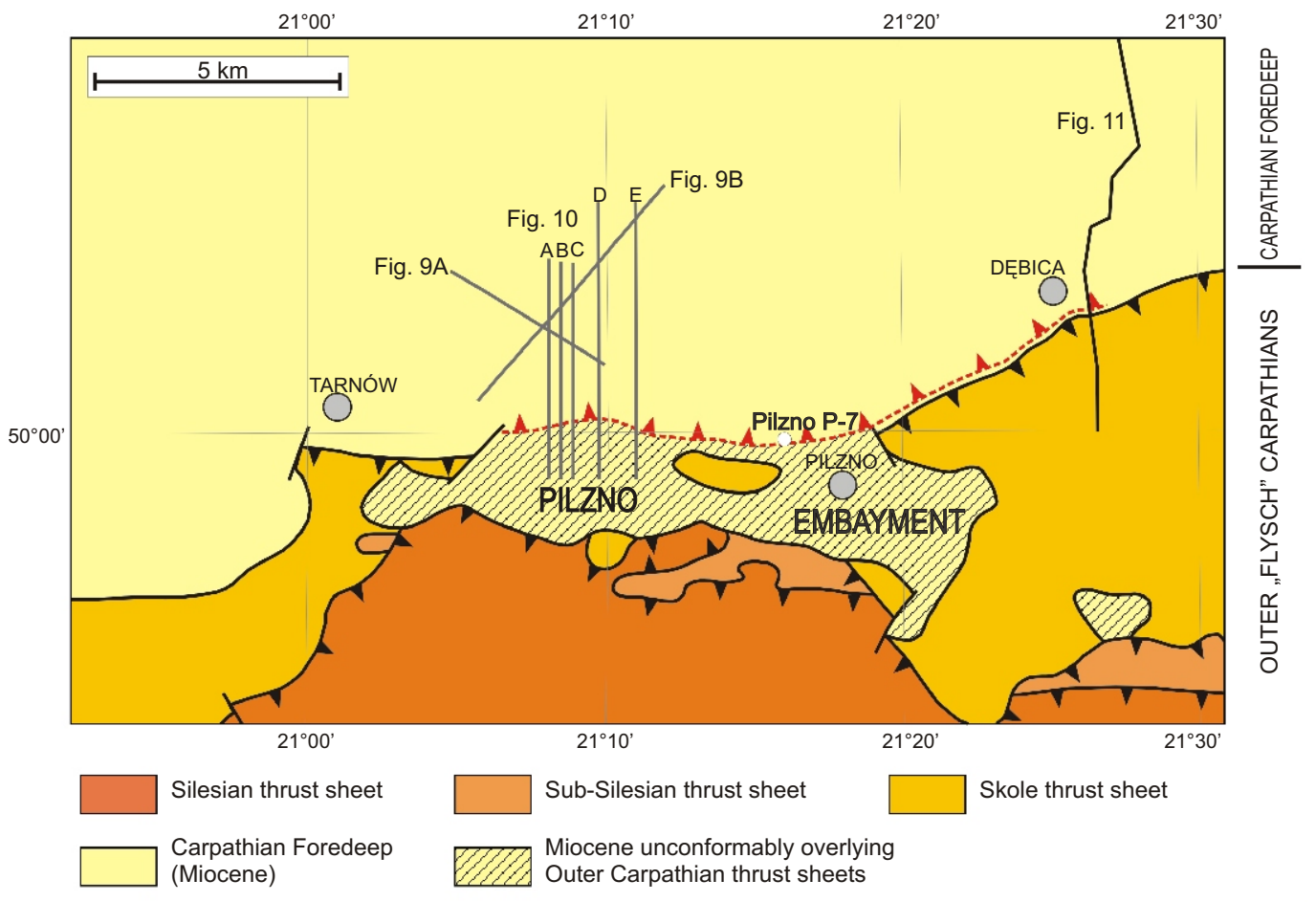

Fig. 3. Location of the interpreted seismic profiles (Figs. 9 and 10), geological cross-section (Fig. 11) and borehole Pilzno P-7, on the background of a geological map of the Outer Carpathians and their foreland without Quaternary formations (Żytko et al., 1989, simplified)

Red hatched line - backthrust along which the supra-evaporitic Miocene sedimentary cover of the Carpathian Foredeep Basin has been thrust towards the south, towards the main Outer Carpathian orogenic wedge (cf. Fig. 10); black lines - main thrusts of the Outer Carpathian thrust belt

well as barren and sulphur-bearing limestone. The thickness of this formation reaches up to $60 \mathrm{~m}$ in the peripheral part of the basin, and up to $20 \mathrm{~m}$ in its central part.

Deposition of evaporites in the Carpathian Foredeep was influenced by numerous factors such as climate, water geochemistry, subsidence, morphology of the sub-evaporitic Meso-Paleozoic substratum, and distance from the basin's coastal areas. According to the model proposed by Garlicki (1979), the chloride facies were deposited in the deepest part of the evaporitic basin, extending between Wieliczka and Pilzno and to the south of this line (Fig. 4; cf. also Poltowicz, 1993; Oszczypko et al., 2006). A vast area located further to the north and covered by the sulphate facies deposits (gypsum and anhydrite) may be regarded as a "saturation shelf" sensu Richter-Bernburg (1955) (cf. Garlicki, 1979).

The morphology of the top of the foreland plate played a crucial role in the deposition of various evaporitic facies (Połtowicz, 1998a, b, 1999; Bukowski, 2011). The whole region between Kraków and Przemyśl is characterized by the presence of NW-SE trending deep palaeovalleys incised into the Mesozoic and/or Paleozoic rocks of the foreland plate (Karpała and Łapinkiewicz, 1962; Połtowicz, 1964, 1998a, b; Połtowicz and Starczewska-Popow, 1973; Karnkowski, 1978, 1989; Moryc, 1995; Krzywiec, 2001; cf. Karnkowski and Ozimkowski, 2001; Krzywiec et al., 2004). Incision of those palaeovalleys might be attributed either to the regional uplift and ensuing erosion of the SE part of the Mid-Polish Swell formed during the Late Cretaceous-Paleogene inversion of the Mid-Polish Trough (see Scheck-Wenderoth et al., 2008 and references therein; Krzywiec, 2009; Krzywiec et al., 2009), or to the Paleogene uplift of the flexural bulge within the Carpathian foreland, a phenomenon characteristic of many underfilled foredeep basins (cf. Sinclair, 1997).
Shallower parts of the basin between Kraków and Dębica were associated with the relatively elevated areas located between deeply incised valleys. They were characterized by sulphate facies (gypsum and anhydrite). Deeper parts of the basin, related to the incised valleys, were associated with halite crystallisation. Later submarine erosion might have partly removed evaporites from the most axial parts of these palaeovalleys (Fig. 4; cf. Połtowicz, 1999).

In the area between Tarnów and Pilzno numerous boreholes drilled during exploration for hydrocarbons provided information on thickness, lithology and facies of the foredeep evaporites (Fig. 5; Cisek and Czernicki, 1964). Following those localized discoveries, a more comprehensive program of exploration for rock salt has been conducted, that was focused on the Pilzno area located to the east of the area analysed in this paper (Gierat-Nawrocka, 1968).

Several boreholes drilled within the axial part of the socalled Jaśniny-Pogórska Wola palaeovalley (e.g., Jaśniny-12, Jaśniny-13, Machowa-6 and Pogórska Wola-16; Połtowicz, 1999; Fig. 5) proved the presence of up an to $400 \mathrm{~m}$ thick internally chaotic evaporitic complex that was interpreted by Połtowicz (1999) as an olistostrome related to submarine mass movements formed during deposition of the evaporites.

\section{DATA AND METHODS}

Several datasets and methods were used to study Miocene evolution of the frontal Carpathian orogenic wedge in the Pogórska Wola area. The main motivation for such an integrated approach was the desire to provide independent constraints on 


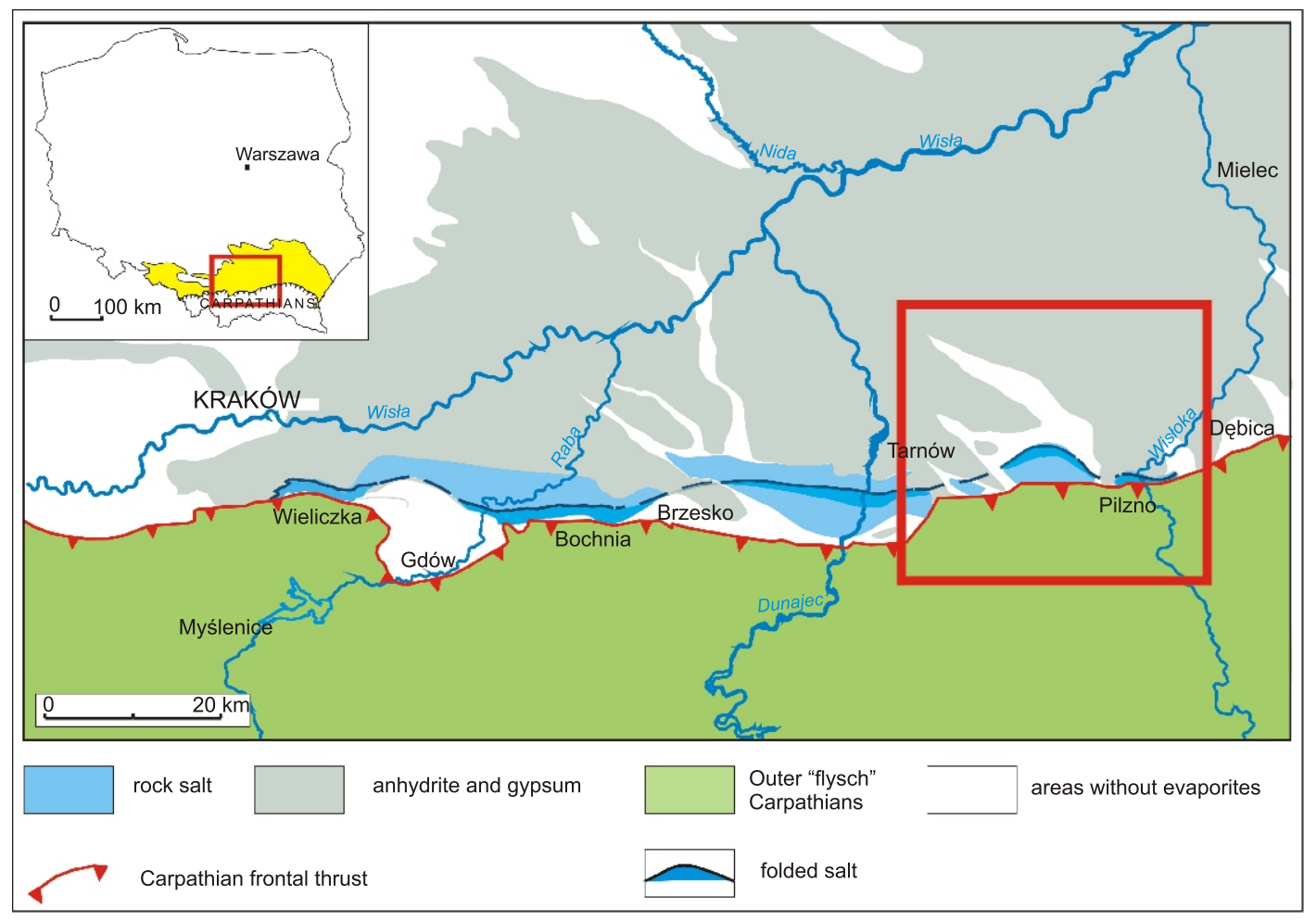

Fig. 4. Occurrence of the Badenian evaporites in the area between Kraków and Dębica (based on Bukowski, 2011)

Red rectangle - area shown on Figure 5

the age, present-day structure and evolution (subsidence and subsequent uplift) of the segment of the Carpathian front studied.

The shallow (187 m) cartographic borehole Pilzno P-7 was drilled on the western periphery of Pilzno, north of the mapped front of the Carpathian orogenic wedge (Fig. 3). It was extensively cored, and this core was used to date the uppermost part of the Miocene infill of the foredeep basin, and, together with the seismic data, to better understand its depositional and structural characteristics (Fig. 6).

The Pilzno P-7 borehole drilled through $18.7 \mathrm{~m}$ of Pleistocene cover and then through tectonically deformed Miocene deposits of the Zgłobice thrust sheet (Fig. 7). Miocene foredeep deposits are represented by a succession of clay-mudstone intercalations with a few fine-medium grained sandstones. In several intervals muddy turbidites were recognized (claystone-siltstone, and fine-to medium-grained sandstone). The shallow part of the borehole (approx. 25-50 m) is characterized by the presence of several intercalations of bright, very fine-grained tuffite (Fig. 7). The entire Miocene succession drilled by the Pilzno P-7 borehole is strongly inclined towards the north, with bed inclinations reaching up to $70^{\circ}$ (Fig. 6). Such strong inclination conforms very well with the overall geometry of this part of the frontal Carpathian wedge observed on seismic data (see below).

Nannofossil studies were used to date Miocene deposits drilled by the Pilzno P-7 shallow borehole. For this purpose core samples were collected from the following depth intervals: 93.0-93.1 m, 94.5-94.6 m, 100.1-100.2 m, 120.1-120.2 m, 154.8-154.9 m, 173.5-173.6 $\mathrm{m}$ and 186.7-186.8 m (Fig. 7). All samples were prepared using the standard smear slide technique and analysed under light microscope (Nikon Eclipse E600POL: LM, 1000x magnification) in plane at parallel and crossed polzarized light. The taxonomic frameworks of Aubry (1984, 1988, 1989, 1990, 1999), Perch-Nielsen (1985) and Bown (1998 and references therein) have been followed. Estimates of the nannofossil abundance for individual samples (Ta- ble 1) were established using the following criteria: $\mathrm{VH}$ (very high): >20 specimens per 1 field of view, $\mathrm{H}$ (high): 10-20 specimens per 1 field of view, $M$ (moderate): $5-10$ specimens per 1 field of view, L (low): 1-5 specimens per 1 field of view, VL (very low): $<5$ specimens per 5 fields of view. In order to visually assess the preservation state of the assemblages the following criteria proposed by Roth and Thierstein (1972) were used: VP (very poor) - etching and mechanical damage is very intensive, specimens mostly as fragments; P (poor) - severe dissolution, fragmentation and/or overgrowth, specific identification of specimens is difficult; $M$ (moderate) - etching or mechanical damage is apparent but most specimens are easily identifiable; $G$ (good) - little dissolution and/or overgrowth, diagnostic characteristics are preserved, the specimens could be identified to species level without any problems.

Results of thermochronological studies provide estimates regarding maximum palaeotemperatures and timing of cooling, and, as a consequence, of maximum burial of the sedimentary sequences studied. One of important questions pertaining to the development of the Carpathian Foredeep infill is the timing and amount of its post-depositional inversion and uplift, either local, e.g. triggered by activity of frontal thrust structures, or more regional, related to the post-orogenic rebound of the lower foreland plate. In an attempt to shed some light on this problem core from the Pilzno P-7 borehole was sampled. Samples for apatite $\mathrm{U}-\mathrm{Th} / \mathrm{He}(\mathrm{AHe})$ and fission-track (AFT) studies were taken from the tuffitic layers located within the depth interval 25-50 m (cf. Fig. 7). The overall state of the core material at the moment of sampling did not allow for unequivocal macroscopic identification of tuffitic intervals. Therefore, and taking into account the fact that all the samples taken from a relatively short depth interval must have experienced identical thermal history, all the samples were treated as one combined sample weighing approximately $5 \mathrm{~kg}$. 


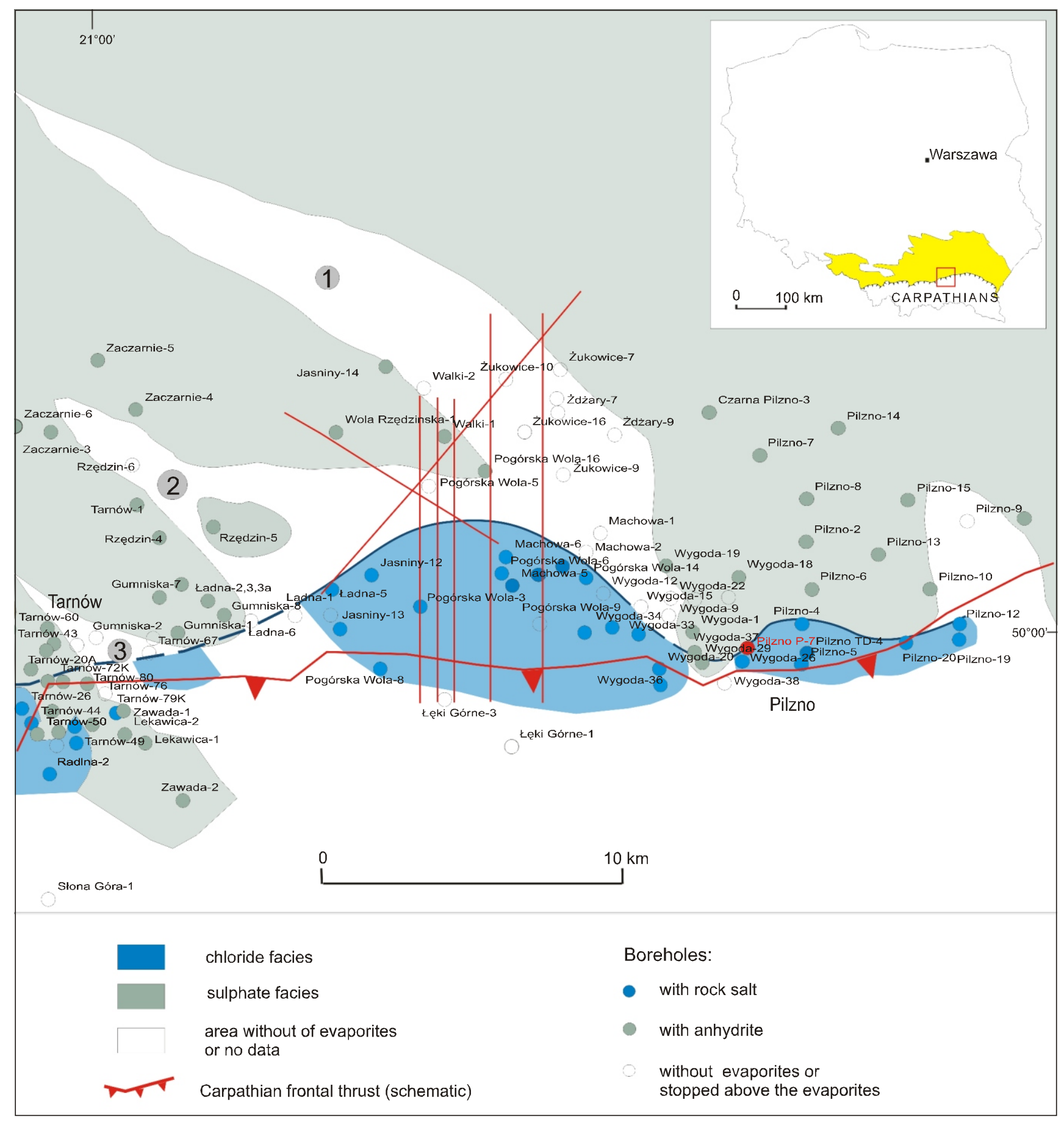

Fig. 5. Occurrence of the Badenian evaporites in the area between Tarnów and Pilzno

Red lines - location of interpreted seismic profiles shown on Figures 9 and 10 (cf. Fig. 3); 1 - Pogórska Wola palaeovalley, 2 - Jaśniny palaeovalley, 3 - Tarnów palaeovalley (cf. Połtowicz, 1999)

A standard separation procedure, described by Donelick et al. (2005), was applied in order to extract apatite crystals. As a result, a small number of apatite crystals was obtained. Most of them were slightly rounded and this suggested that they might have been transported in water, and/or otherwise weathered. From the entire population of extracted apatite 5 euhedral crystals ( 80 to $250 \mu \mathrm{m}$ long and 60 to $110 \mu \mathrm{m}$ in diameter) were selected, characterized by the lack of any significant cracks and inclusions. These selected crystals were used for AHe studies; the remaining crystals were used for AFT analysis.

AHe studies were performed following the general procedures described by Farley et al. (1996), Wolf et al. (1996) and
Farley (2000). Content of He was measured using a Quadrupole Mass Spectrometer Hiden HAL3F, and the content of $238 \mathrm{U}$ and of 232Th was measured using a Plasmaquad PQ2.5 ICP-MS spectrometer. Age determinations were completed following standard procedures described by Farley et al. (1996) and Meesters and Dunai (2005).

Apatite fission-track (AFT) studies were performed using the external detector method (EDM; Gleadow and Lovering, 1977). The samples were radiated using a nuclear reactor in Oregon including a CN5 glass dosimeter. The zeta calibration method was used for age determination (Hurford and Green, 1983), Durango apatite was used for age calibration, and the fi- 

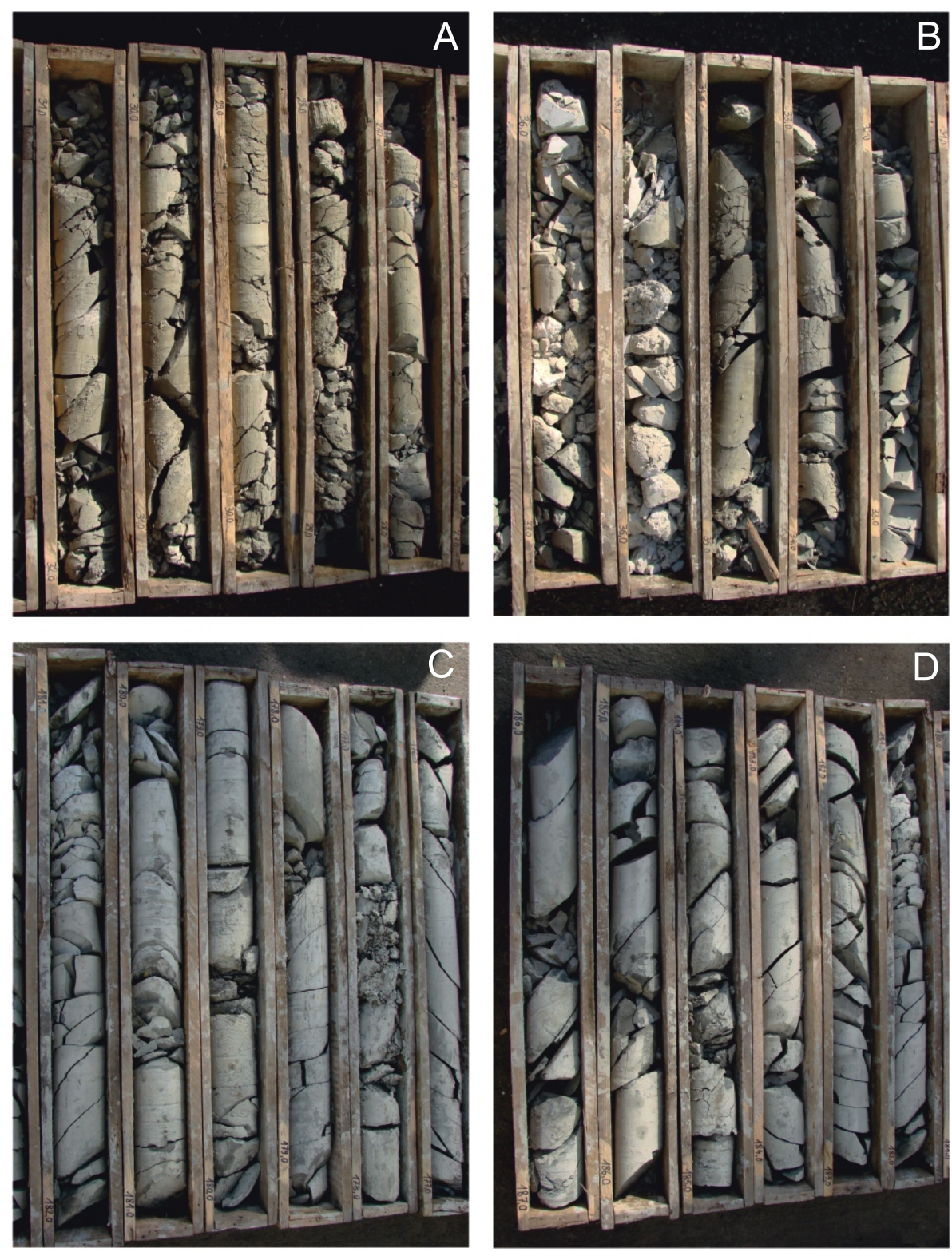

Fig. 6. Pilzno P-7 borehole - core photographs showing steep inclination of the Sarmatian foredeep infill within the deformed Zgłobice Unit

A - depth interval $27.0-31.0 \mathrm{~m}$ : clay/mudstone sequence with tuffite intercalations; $\mathbf{B}$ - depth interval 32.0-36.0 m: grey laminated mudstones, inclination 55-60; C - depth interval 176.0-181.0 m: grey marly mudstones with thin intercalations (up to $4 \mathrm{~mm}$ ) of dark claystone and very fine sandstone, inclination $50^{\circ}$; D - depth interval $181.0-186.0 \mathrm{~m}$ : dark grey marly mudstones with inclination of $45^{\circ}$; high stratal dips are compatible with the structural model derived from seismic data (cf. Fig. 10)

nal fission track age was calculated using Trackkey software (Dunkl, 2002). The small amount and relatively low quality of crystal samples studied precluded track length analysis.

Seismic data was used to visualize the present-day structure of the frontal Carpathian orogenic wedge. The available data consisted of several NW-SE or SW-NE oriented 2D seismic profiles and of several tens of 2D profiles extracted from the "Pogórska Wola" 3D seismic survey (Ochał and Borowska, 1995). All this data, provided by Geofizyka Kraków in SEGY format, was post-stack time-migrated.

\section{RESULTS}

\section{CALCAREOUS NANNOPLANKTON}

The abundance pattern in the samples studied from the Pilzno P-7 borehole varies from high $(\mathrm{H})$ to very high $(\mathrm{VH})$. The preservation of calcareous nannofossils was moderate $(\mathrm{M})$ or predominantly moderate to good $(G)$ in all samples investigated (Table 1; cf. Fig. 8). Nannofossils show minor etching and minor to moderate overgrowth. 


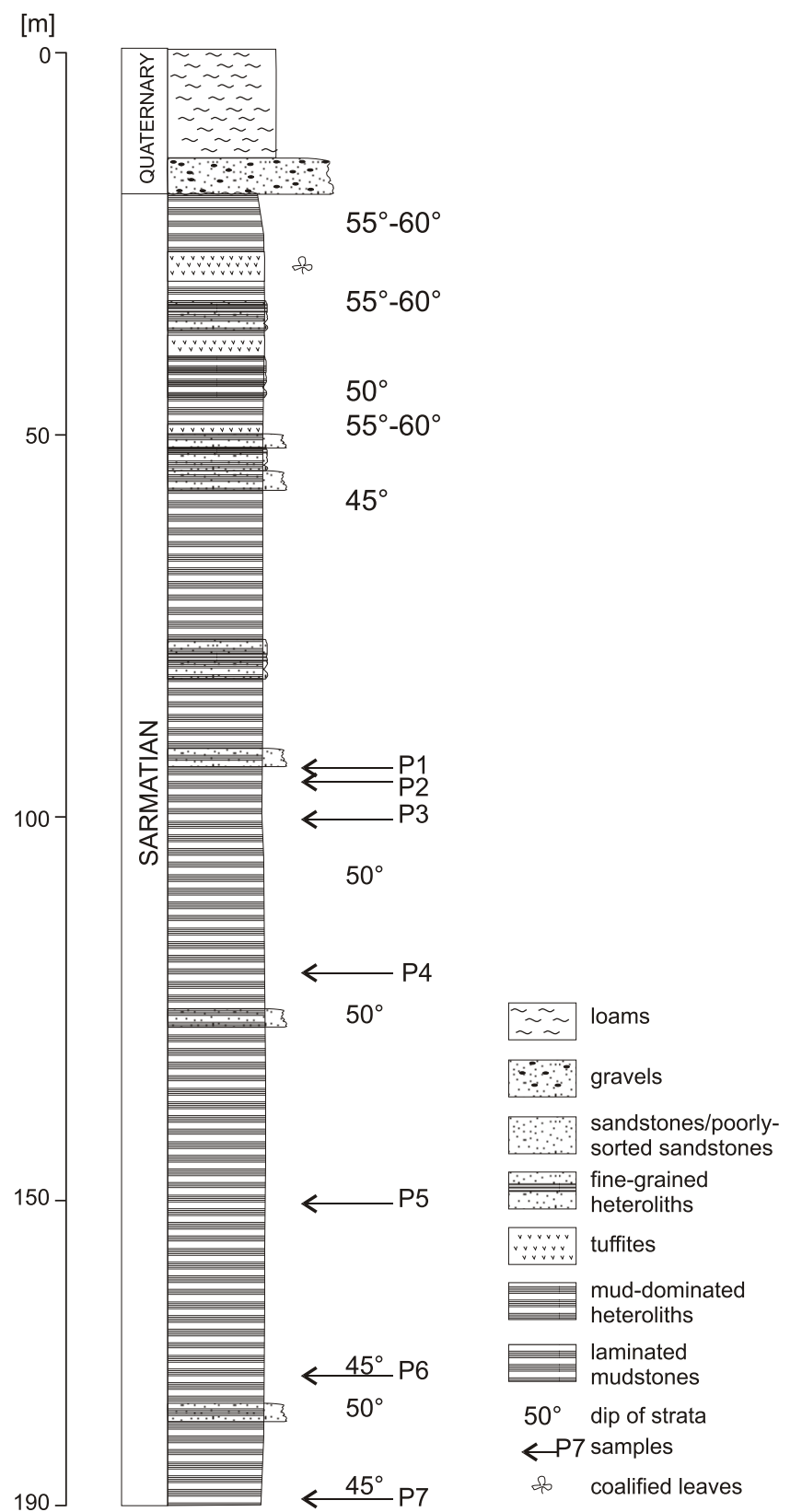

Fig. 7. Pilzno P-7 borehole - sedimentological log of the Sarmatian deposits located above the backthrust developed in front of the Outer Carpathians (cf. Fig. 10)

P1-P7 - location of samples taken for nannofossil studies

The autochthonous assemblage is represented by: Calcidiscus leptoporus (Murray and Blackman), Coccolithus miopelagicus Bukry, C. pelagicus (Wallich), Coronocyclus nitescens (Kamptner), Cyclicargolithus floridanus (Roth and Hay), Discoaster deflandrei Bramlette and Riedel, D. exilis Martini and Bramlette, D. variabilis Martini and Bramlette, Helicosphaera carteri (Wallich), $H$. compacta Bramlette and Wilcoxon, $H$. euphratis Haq, $H$. intermedia Martini, $H$. mediterranea Müller, $H$. walbersdorfensis Müller, Pontosphaera multipora (Kamptner), $P$. plana (Bramlette and Sullivan), Reticulofenestra minuta Roth, $R$. pseudoumbilica (Gartner), Sphenolithus abies (Deflandre in Deflandre and Fert), Sphenolithus moriformis (Bronnimann and Stradner) and Umbilicosphaera rotula (Kamptner). The most common (1 species/observation field) are: Cyclicargolithus floridanus and Coccolithus pelagicus, whereas Helicosphaera carteri, Reticulofenestra pseudoumbilica, Sphenolithus abies and Sph. moriformis are present to lesser extent. Helicosphaera walbersdorfensis is very rare.

The allochthonous assemblage constitutes approximately $30 \%$ of all identified species. The most common species are of Late Eocene and Oligocene age. Percentages of Cretaceous species are very low. The Late Eocene assemblage is composed mainly of Isthmolithus recurvus Deflandre, Ericsonia formosa (Kamptner), Reticulofenestra reticulata (Gartner and Smith) and R. umbilica (Levin), and the Oligocene assemblage contains Cyclicargolithus abisectus (Müller), Helicosphaera perch-nielseniae, H. recta Haq, Pontosphaera latelliptica (BaldiBeke and Baldi), P. rothi Haq, Reticulofenestra lockerii Müller, $R$. ornata Müller and Transversopontis obliquipons (Deflandre).

According to the standard zonation of Martini (1971) and Martini and Worsley (1970), the stratigraphic event marking the lower boundary of NN7 is the first occurrence of Discoaster kugleri Martini and Bramlette. However, this species is extremely rare, and therefore it was necessary to use a secondary index species such as Calcidiscus premacintyrei. The last common occurrence of Calcidiscus premacintyrei takes place just before the first occurrence of Discoaster kugleri (see Fornaciari and Rio, 1996), so it can approximate the boundary between the NN6 and NN7 zones. Both species Discoaster kugleri and Calcidiscus premacintyrei are not present in the assemblage. The other alternative species used to approximate zone NN7 are Cacidiscus macintyrei and Coccolithus miopelagicus $(>14 \mu \mathrm{m})$. The presence of Coccolithus miopelagicus $(>14 \mu \mathrm{m})$ is essentially confined just to that interval, but its first occurrence is gradational (Young, 1998). According to Fornaciari and Rio (1996) and Young (1998), the first appearance of Cacidiscus macintyrei takes place near the NN6/NN7 boundary. However, Švábenická (2002) and Ćorić and Švábenická (2004) describe this species as early as from zone NN6 and even from zone NN5. At the same time, species such as Sphenolithus abies and Helicosphaera stalis are present and are characteristic of zones NN6 and higher (cf. Young, 1998). The co-occurrence of Cacidiscus macintyrei, Coccolithus miopelagicus $(>14 \mu \mathrm{m})$ and Helicosphaera walbersdorfensis and absence of Calcidiscus premacintyrei allow assigning the assemblages from the Pilzno-7 borehole to zone NN7, i.e. to the Sarmatian (Fig. 2; see also Oszczypko-Clowes et al., 2012).

\section{THERMOCHRONOLOGY}

A relationship between $\mathrm{AHe}$ age and $U$ and Th content as well as crystal shape has not been observed. Five crystals analysed gave ages spread between $35.8 \pm 1.4 \mathrm{Ma}$ and $10.5 \pm$ $1.3 \mathrm{Ma}$. Mean age for the two youngest crystals that had similar ages was $11.6 \pm 1.5 \mathrm{Ma}$ (Table 2).

An AFT age was determined for just 13 crystals as the quality of the remaining material precluded fission-track analysis. Results for those crystals were regarded as belonging to a single population characterized by a central age of $13.2 \pm 2.2 \mathrm{Ma}$ (Table 3).

Previously completed studies of compaction of the Miocene infill of the Carpathian Foredeep suggested that the zone of maximum erosion and exhumation of about $1000 \mathrm{~m}$ was located between Przemyśl and Rzeszów, in the vicinity of the present-day frontal thrust of the Carpathian orogenic wedge (Poprawa et al., 2002). Lower values of post-orogenic exhumation, about $400-800 \mathrm{~m}$, have been provided by the illitesmectite method (Środoń, 1984). Exhumation might have been related to the removal of the uppermost part of the foredeep 
Nannofossil distribution from the Pilzno P-7 borehole

\begin{tabular}{|c|c|c|c|c|c|c|c|}
\hline Sample number & $\mathrm{P} 1$ & P2 & P3 & $\mathrm{P} 4$ & P5 & P6 & $\mathrm{P} 7$ \\
\hline Sample abundance & VH & M & $\mathrm{M}$ & $\mathrm{H}$ & $\mathrm{M}$ & $\mathrm{M}$ & $\mathrm{L}$ \\
\hline Nannofossil preservation & G & G & $\mathrm{M}$ & G & G & $\mathrm{M}$ & $\mathrm{M}$ \\
\hline Braarudosphaera bigelowii & & $\mathrm{X}$ & $X$ & & $X$ & & $\mathrm{X}$ \\
\hline Calcidiscus leptoporus & & $\mathrm{X}$ & & & $\mathrm{X}$ & & $\mathrm{X}$ \\
\hline Calcidiscus macintyrei & $X$ & $\mathrm{X}$ & $\mathrm{X}$ & $\mathrm{X}$ & $\mathrm{X}$ & $\mathrm{X}$ & $X$ \\
\hline Coccolithus miopelagicus & $X$ & $X$ & $X$ & $\mathrm{x}$ & $X$ & $\mathrm{X}$ & $\mathrm{X}$ \\
\hline Coccolithus miopelagicus $>10 \mu \mathrm{m}$ & $\mathrm{X}$ & $\mathrm{X}$ & $\mathrm{X}$ & $\mathrm{x}$ & $\mathrm{X}$ & $\mathrm{X}$ & $\mathrm{X}$ \\
\hline Coccolithus pelagicus & $\mathrm{X}$ & $\mathrm{X}$ & $\mathrm{X}$ & $\mathrm{x}$ & $\mathrm{X}$ & $\mathrm{X}$ & $\mathrm{X}$ \\
\hline Coronocyclus nitescens & $\mathrm{X}$ & $\mathrm{X}$ & $\mathrm{X}$ & $\mathrm{X}$ & $\mathrm{X}$ & $\mathrm{X}$ & $\mathrm{X}$ \\
\hline Cretaceous species undivided & $\mathrm{R}$ & $\mathrm{R}$ & $\mathrm{R}$ & $\mathrm{R}$ & $\mathrm{R}$ & $\mathrm{R}$ & $\mathrm{R}$ \\
\hline Cribocentrum reticulatum & $\mathrm{R}$ & $\mathrm{R}$ & $\mathrm{R}$ & $\mathrm{R}$ & $\mathrm{R}$ & $\mathrm{R}$ & $\mathrm{R}$ \\
\hline Cyclicargolithus abisectus & $\mathrm{R}$ & $\mathrm{R}$ & $\mathrm{R}$ & $\mathrm{R}$ & $\mathrm{R}$ & $\mathrm{R}$ & $\mathrm{R}$ \\
\hline Cyclicargolithus floridanus & $\mathrm{X}$ & $\mathrm{X}$ & $x$ & $x$ & $\mathrm{X}$ & $\mathrm{x}$ & $\mathrm{X}$ \\
\hline Dictyococcites bisectus & $\mathrm{R}$ & $\mathrm{R}$ & $\mathrm{R}$ & $\mathrm{R}$ & $\mathrm{R}$ & $\mathrm{R}$ & $\mathrm{R}$ \\
\hline Discoaster deflandrei & $\mathrm{X}$ & $\mathrm{X}$ & $\mathrm{X}$ & & $\mathrm{X}$ & & $\mathrm{X}$ \\
\hline Discoaster exilis & $\mathrm{X}$ & $X$ & $\mathrm{X}$ & & $\mathrm{X}$ & $\mathrm{X}$ & \\
\hline Ericsonia fenestrata & $\mathrm{R}$ & & $\mathrm{R}$ & & $\mathrm{R}$ & & $\mathrm{R}$ \\
\hline Ericsonia formosa & $\mathrm{R}$ & $\mathrm{R}$ & $\mathrm{R}$ & $\mathrm{R}$ & $\mathrm{R}$ & $\mathrm{R}$ & $\mathrm{R}$ \\
\hline Ericsonia subdisticha & $\mathrm{R}$ & $\mathrm{R}$ & $\mathrm{R}$ & $\mathrm{R}$ & $\mathrm{R}$ & $\mathrm{R}$ & $\mathrm{R}$ \\
\hline Helicosphaera carteri & $\mathrm{X}$ & $\mathrm{X}$ & $\mathrm{X}$ & $x$ & $\mathrm{X}$ & $\mathrm{X}$ & $\mathrm{X}$ \\
\hline Helicosphaera compacta & $\mathrm{R}$ & $\mathrm{R}$ & $\mathrm{R}$ & $\mathrm{R}$ & $\mathrm{R}$ & $\mathrm{R}$ & $\mathrm{R}$ \\
\hline Helicosphaera euphratis & $\mathrm{R}$ & $\mathrm{R}$ & $\mathrm{R}$ & $\mathrm{R}$ & $\mathrm{R}$ & $\mathrm{R}$ & $\mathrm{R}$ \\
\hline Helicosphaera intermedia & $\mathrm{X}$ & $\mathrm{X}$ & $\mathrm{X}$ & $\mathrm{x}$ & $\mathrm{X}$ & $\mathrm{X}$ & \\
\hline Helicosphaera mediterranea & $\mathrm{R}$ & $\mathrm{R}$ & $\mathrm{R}$ & $\mathrm{R}$ & $\mathrm{R}$ & $\mathrm{R}$ & $\mathrm{R}$ \\
\hline Helicosphaera recta & & $\mathrm{R}$ & & & $\mathrm{R}$ & & $\mathrm{R}$ \\
\hline Helicosphaera stalis & $\mathrm{X}$ & $\mathrm{X}$ & $\mathrm{X}$ & $\mathrm{X}$ & $\mathrm{X}$ & $\mathrm{X}$ & $\mathrm{X}$ \\
\hline Helicosphaera walbersdorfensis & $\mathrm{X}$ & $\mathrm{X}$ & $\mathrm{X}$ & $\mathrm{x}$ & $\mathrm{X}$ & $\mathrm{X}$ & $\mathrm{X}$ \\
\hline Isthmolithus recurvus & $\mathrm{R}$ & $\mathrm{R}$ & $\mathrm{R}$ & $\mathrm{R}$ & $\mathrm{R}$ & $\mathrm{R}$ & $\mathrm{R}$ \\
\hline Lanternithus minutus & $\mathrm{R}$ & & $\mathrm{R}$ & $\mathrm{R}$ & $\mathrm{R}$ & $\mathrm{R}$ & \\
\hline Neococcolithes dubius & & $\mathrm{R}$ & & $\mathrm{R}$ & & $\mathrm{R}$ & \\
\hline Pontosphaera latelliptica & & $\mathrm{R}$ & & $\mathrm{R}$ & $\mathrm{R}$ & & \\
\hline Pontosphaera multipora & $\mathrm{X}$ & $X$ & & & $\mathrm{X}$ & & $\mathrm{X}$ \\
\hline Pontosphaera plana & & $\mathrm{R}$ & & & $\mathrm{R}$ & & \\
\hline Pontosphaera rothi & & $\mathrm{R}$ & & & $\mathrm{R}$ & & \\
\hline Reticulofenestra dictyoda & $\mathrm{R}$ & $\mathrm{R}$ & & & & & \\
\hline Reticulofenestra lockerii & $\mathrm{R}$ & $\mathrm{R}$ & & & & & \\
\hline Reticulofenestra ornata & & $\mathrm{R}$ & & & & $\mathrm{R}$ & \\
\hline Reticulofenestra pseudoumbilica & $\mathrm{X}$ & $\mathrm{X}$ & $\mathrm{X}$ & & & & \\
\hline Reticulofenestra spp. small & $\mathrm{X}$ & $\mathrm{X}$ & $\mathrm{X}$ & $\mathrm{X}$ & $X$ & $\mathrm{X}$ & $\mathrm{X}$ \\
\hline Reticulofenestra umbilica & $\mathrm{R}$ & $\mathrm{R}$ & $\mathrm{R}$ & & $\mathrm{R}$ & $\mathrm{R}$ & \\
\hline Rhabdosphaera sicca & $\mathrm{X}$ & $\mathrm{X}$ & $\mathrm{X}$ & $\mathrm{x}$ & $\mathrm{X}$ & $\mathrm{X}$ & $\mathrm{X}$ \\
\hline Sphenolithus abies & $\mathrm{X}$ & $X$ & $\mathrm{X}$ & $\mathrm{X}$ & $\mathrm{X}$ & $\mathrm{X}$ & $\mathrm{X}$ \\
\hline Sphenolithus dissilimis & $\mathrm{R}$ & $\mathrm{R}$ & $\mathrm{R}$ & $\mathrm{R}$ & $\mathrm{R}$ & $\mathrm{R}$ & $\mathrm{R}$ \\
\hline Sphenolithus moriformis & $\mathrm{X}$ & $\mathrm{X}$ & $\mathrm{X}$ & $\mathrm{x}$ & $\mathrm{X}$ & $\mathrm{x}$ & $\mathrm{X}$ \\
\hline Transersopontis obliquipons & $\mathrm{R}$ & $\mathrm{R}$ & & $\mathrm{R}$ & $\mathrm{R}$ & $\mathrm{R}$ & \\
\hline Transversopontis pulcheroides & & $\mathrm{R}$ & & $\mathrm{R}$ & $\mathrm{R}$ & & \\
\hline Triquetrorhabdulus rioi & $\mathrm{X}$ & & $\mathrm{X}$ & & & $\mathrm{x}$ & \\
\hline Umbilicosphaera rotula & $\mathrm{X}$ & $\mathrm{X}$ & $\mathrm{X}$ & $\mathrm{x}$ & $\mathrm{X}$ & $X$ & $\mathrm{X}$ \\
\hline Zygrhablithus bijugatus & $\mathrm{R}$ & & $\mathrm{R}$ & $\mathrm{R}$ & $\mathrm{R}$ & $\mathrm{R}$ & \\
\hline
\end{tabular}

$\mathrm{X}$ - determined species, $\mathrm{R}$ - reworked species; for other explanations see text 

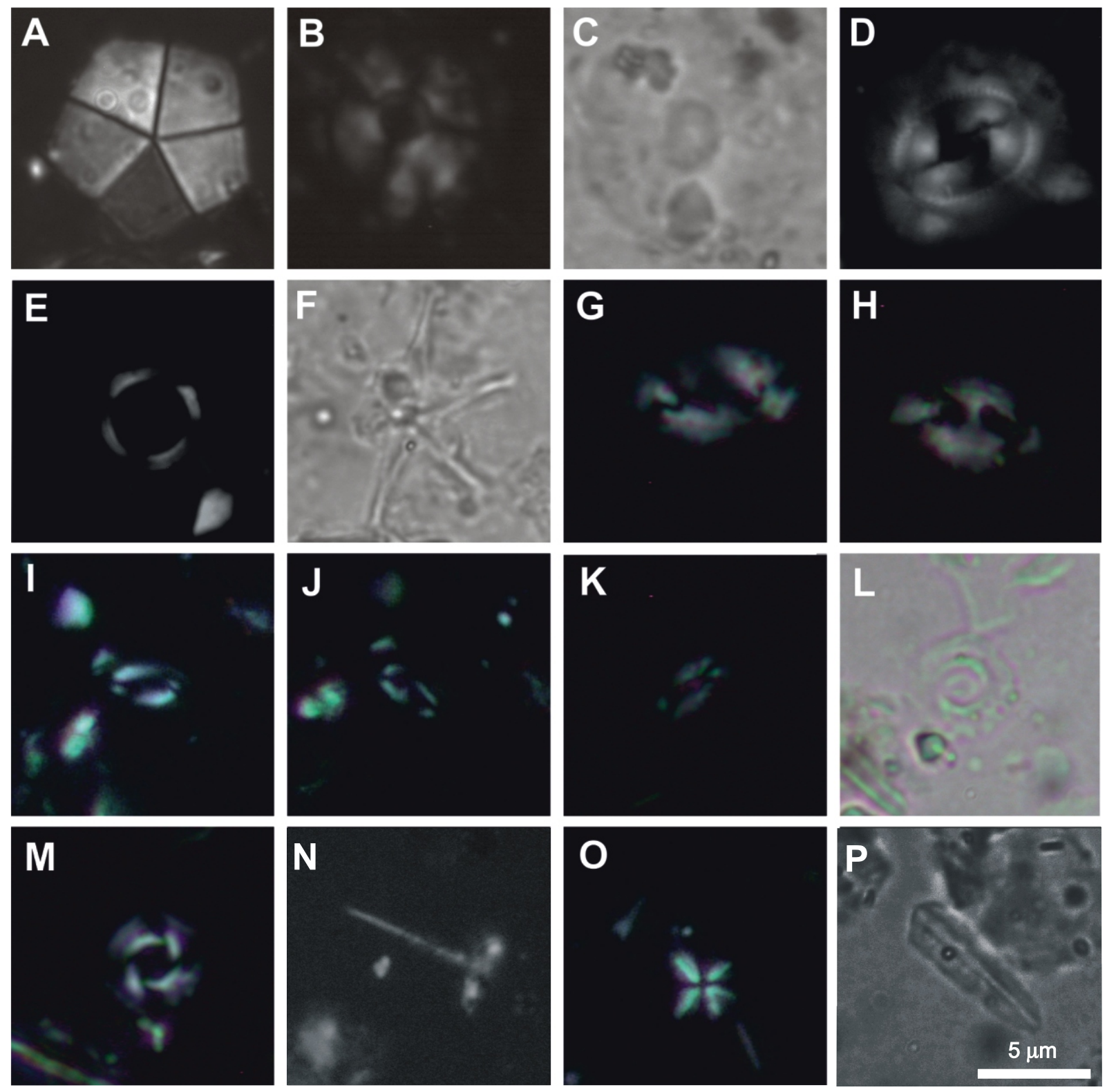

Fig. 8. Pilzno P-7 borehole - photomicrographs of the typical Miocene nannofossil assemblages identified in core samples

A - Braarudosphaera bigelowii (sample P2); B, C - Calcidiscus macintyrei (sample P7); D - Coccolithus miopelagicus (sample P4); E - Coronocyclus nitescens (sample P5); F - Discoaster exilis (sample P3); G - Helicosphaera carteri (sample P2); H Helicosphaera carteri (sample P5); I, J - Helicosphaera stalis (sample P7); K - Helicosphaera walbersdorfensis (sample P7); L, M - Reticulofenestra pseudoumbilica (sample P5); N-Rhabdosphaera sicca (sample P2); O - Sphenolithus abies (sample P7); $\mathbf{P}$ - Triquetrorhabdulus rioi (sample P1)

infill. For the Pilzno area, where the Pilzno P-7 borehole is located, compaction analysis indicates approximately $600 \mathrm{~m}$ of exhumation (Poprawa et al., 2002).

Results of AHe studies showed the existence of two populations of apatite crystals. The first of these includes crystals characterized by ages significantly higher than the age of the Miocene Carpathian infill, about 36 to $18 \mathrm{Ma}$ (Table 2). This suggests that these crystals have not been deposited directly to the foredeep from the ash cloud. Their age is comparable to the results of AHe studies from the Outer Carpathians (cf. Mazzoli et al., 2010; Andreucci et al., 2013) and this might suggest that these crystals were re-deposited and transported to the Carpathian Foredeep Basin from the eroded Outer Carpathian thrust sheets. The second group of apatite crystals is characterized by an age of $11.6 \pm 1.5 \mathrm{Ma}$. Such a AHe age is replicated by the AFT results, with all dated crystals belonging to one population with a mean age of $13.2 \pm 2.2$ Ma. Cooling ages of both thermochronometers are directly comparable to the Sarmatian sedimentation age of the Pilzno P-7 borehole strata revealed by micropalaeontological investigations (ca. $<11.9 \mathrm{Ma}$ ). Therefore, it was assumed that most of the apatite crystals are of pyroclastic origin despite signs of weathering. The results strongly suggest that rocks sampled were not buried deeply enough to significantly reset their ages $\left(\sim 50-70^{\circ} \mathrm{C}\right.$ for $\mathrm{AHe}$ and $\sim 70-110^{\circ} \mathrm{C}$ for $\mathrm{AFT}$ ). In such a case neither of the low temperature thermochronometers used is capable of recording the tim- 


\section{AHe results}

\begin{tabular}{|l|c|c|c|c|c|c|c|c|c|c|c|c|}
\hline $\begin{array}{c}\text { Sample } \\
\text { name }\end{array}$ & $\begin{array}{c}\text { Th } \\
{[\mathrm{ng}]}\end{array}$ & $\begin{array}{c}\text { Th error } \\
{[\%]}\end{array}$ & $\begin{array}{c}\mathrm{U} \\
{[\mathrm{ng}]}\end{array}$ & $\begin{array}{c}\mathrm{U} \text { error } \\
{[\%]}\end{array}$ & $\begin{array}{c}\mathrm{He} \\
{\left[10^{-10} \mathrm{~cm}^{3}\right]}\end{array}$ & $\begin{array}{c}\mathrm{He} \text { error } \\
{[\%]}\end{array}$ & $\begin{array}{c}\text { TAU } \\
{[\%]}\end{array}$ & Th/U & $\begin{array}{c}\text { Unc. age } \\
{[\mathrm{Ma}]}\end{array}$ & $\mathrm{F}_{\mathrm{T}}$ & $\begin{array}{c}\text { Corrected } \\
\text { age }[\mathrm{Ma}]\end{array}$ & $\begin{array}{c} \pm 1 \sigma \\
{[\mathrm{Ma}]}\end{array}$ \\
\hline P7\#1 & 0.062 & 6.4 & 0.014 & 7.0 & 0.432 & 0.5 & 9.5 & 4.32 & 10.4 & 0.555 & 22.2 & 2.1 \\
\hline P7\#2 & 0.048 & 8.2 & 0.011 & 9.0 & 0.164 & 0.6 & 12.1 & 4.33 & 4.9 & 0.577 & 10.5 & 1.3 \\
\hline P7\#3 & 0.090 & 4.4 & 0.019 & 5.4 & 0.470 & 0.5 & 7.0 & 4.80 & 8.5 & 0.760 & 12.6 & 0.9 \\
\hline P7\#4 & 0.298 & 1.7 & 0.085 & 1.7 & 2.582 & 0.5 & 2.4 & 3.50 & 13.2 & 0.758 & 18.0 & 0.4 \\
\hline P7\#5 & 0.114 & 3.6 & 0.086 & 1.6 & 3.827 & 0.5 & 4.0 & 1.32 & 26.5 & 0.777 & 35.8 & 1.4 \\
\hline
\end{tabular}

Th - amount of ${ }^{232} \mathrm{Th}$; Th error - 1 sigma error of Th volume estimation; $U$ - amount of ${ }^{238} \mathrm{U} ; \mathrm{U}$ error - 1 sigma error of $\mathrm{U}$ volume estimation; $\mathrm{He}-{ }^{4} \mathrm{He}$ volume at standard conditions of temperature and pressure; He error -1 sigma error of He volume estimation; TAU - total analytical uncertainty; Th/U - ${ }^{232} \mathrm{Th}$ to ${ }^{238} \mathrm{U}$ factor; Unc. age - uncorrected He age; $\mathrm{F}_{\mathrm{T}}$ - alpha recoil correction factor after Farley et al. (1996); corrected age $[\mathrm{Ma}]$ - corrected He age; $\pm 1 \sigma$ - sigma standard deviation of corrected age

\section{Apatite fission track results}

\begin{tabular}{|c|c|c|c|c|c|c|c|c|c|c|c|}
\hline $\mathrm{N}$ & $\rho_{\mathrm{s}}\left(\mathrm{e}^{\wedge} 5\right)$ & $\mathrm{N}_{\mathrm{s}}$ & $\rho_{\mathrm{i}}\left(\mathrm{e}^{\wedge} 5\right)$ & $\mathrm{N}_{\mathrm{i}}$ & $\rho_{\mathrm{d}}\left(10^{5}\right)$ & $\mathrm{N}_{\mathrm{d}}$ & $\begin{array}{c}\mathrm{P}(\chi 2) \\
{[\%]}\end{array}$ & $\begin{array}{c}\text { Age } \\
{[\mathrm{Ma}]}\end{array}$ & $\begin{array}{c} \pm 1 \sigma \\
{[\mathrm{Ma}]}\end{array}$ & $\begin{array}{c}\text { Dpar } \\
{[\mu \mathrm{m}]}\end{array}$ & $\begin{array}{c} \pm 1 \sigma \\
{[\mu \mathrm{m}]}\end{array}$ \\
\hline 13 & 0.0121 & 39 & 0.2568 & 826 & 15.1800 & 9195 & 100 & 13.2 & 2.2 & 1.86 & 0.13 \\
\hline
\end{tabular}

$\mathrm{N}$ - number of crystals; $\rho_{\mathrm{s}}$ - spontaneous track density [per $\mathrm{cm}^{2}$ ]; $\mathrm{N}_{\mathrm{s}}$ - number of counted spontaneous tracks; $\rho_{\mathrm{i}}-$ induced track density [per $\left.\mathrm{cm}^{2}\right] ; \mathrm{N}_{i}-$ number of counted induced tracks; $\rho_{d}-$ dosimeter track density $\left[\right.$ per $\left.\mathrm{cm}^{2}\right] ; \mathrm{N}_{d}-$ number of tracks counted on dosimeter; $\mathrm{P}(\chi 2)-\operatorname{prob}-$ ability for obtaining chi-square value for single population test; Age - central age; $\pm 1 \sigma[\mathrm{Ma}]$ - sigma error for age; Dpar - value of average etch pit diameter of fission tracks, Durango apatite standard Dpar - $1.81 \pm 0.1$ (Carlson et al., 1999); $\pm 1 \sigma[\mu \mathrm{m}]$ - standard deviation for Dpar

ing of exhumation but they can limit maximum palaeotemperatures and, as a consequence, also maximum burial. This can be estimated as $1.5-2.0 \mathrm{~km}$, assuming a palaeo-geothermal gradient of the order of $25-30^{\circ} \mathrm{C} / \mathrm{km}$ (cf. Górecki, 2011; Majorowicz and Wybraniec, 2011).

\section{SEISMIC DATA INTERPRETATION}

Seismic data acquired within the study area was used to illustrate the structure and gross depositional architecture of the Miocene foredeep infill (Figs. 9 and 10). In this part of the basin most of the 2D seismic profiles are located NW-SE and $\mathrm{NE}-\mathrm{SW}$ as they were acquired perpendicular and parallel to the main NW-SE structural trend within the pre-Miocene basement, in a regional sense determined by the Teisseyre-Tornquist Zone (see e.g. Krzywiec, 2001 for further details). The most prominent features related to this regional basement trend are deep sub-Miocene palaeovalleys incised into the Meso-Paleozoic foreland plate (Fig. 5). Both seismic lines in Figure 9 show the Jaśniny palaeovalley, line (B) also shows the deeply incised Pogórska Wola palaeovalley (Połtowicz, 1999; Fig. 5). Above the northern slope of the Jaśniny palaeovalley a compressional structure (the so-called Jaśniny structure; cf. Baran and Jawor, 1994) is developed within the Miocene foredeep infill. This structure hosts the Jaśniny gas field (Baran and Jawor, 1994).

The compressional character of the Jaśniny structure was suggested for the first time by Baran and Jawor (1994). It can be classified as a fault-propagation fold that formed above the northern slope of the Jaśniny palaeovalley due to the buttressing effect exerted by this slope, i.e. by the morphological high within the pre-Miocene basement, similarly to e.g. the Biadoliny structure located west of Tarnów (Krzywiec, 2001; Krzywiec et al., 2004; Nemčok et al., 2006; Krzywiec and Vergés, 2007). This structure can be also classified as a buried or blind frontal thrust (Boyer and Elliott, 1982; Morley, 1986; Dunne and Ferril, 1988) of this segment of the entire Carpathian orogenic wedge.

One of the characteristic features of the Jaśniny thrust front, very clearly visible on seismic data, are thickness reductions of the Miocene packages within the crest of the fold (i.e. the growth strata; cf. Medwedeff, 1989; Suppe et al., 1992), accompanied by localized erosion and the presence of progressive unconformities (cf. Ori et al., 1986). All these features are very typical of growth folds that often develop syndepositionally in frontal parts of orogenic belts, within the foredeep basins (e.g., Ori et al., 1986; Artoni and Casero, 1997; Ford et al., 1997).

Figure 10 shows five seismic profiles extracted from the "Pogórska Wola" 3D seismic survey. This seismic survey is partly located within the axial part of the Jaśniny-Pogórska Wola palaeovalley system, and partly above the Outer Carpathian frontal Skole thrust sheet covered by the Miocene foredeep deposits of the Pilzno embayment (Figs. 3 and 5). Because of its location, this seismic survey illustrates important lateral changes of the Jaśniny thrust structure.

The Jaśniny structure, detached above the Upper Badenian foredeep evaporites, has been imaged on profiles $A, B$ and $C$, although the amount of displacement is different on each of these profiles. The westernmost profile $A$ is located above the relatively steep northern slope of the Jaśniny palaeovalley (Fig. 5), where the Jaśniny structure is characterized by significant amounts of displacement and clearly visible localized thinning of the lower part of the Miocene foredeep infill within its crestal part, similarly to the two seismic examples described above. Essentially the same geometry of this structure can be seen on profile $B$, but profile $\mathrm{C}$ shows the eastern termination of the Jaśniny structure 

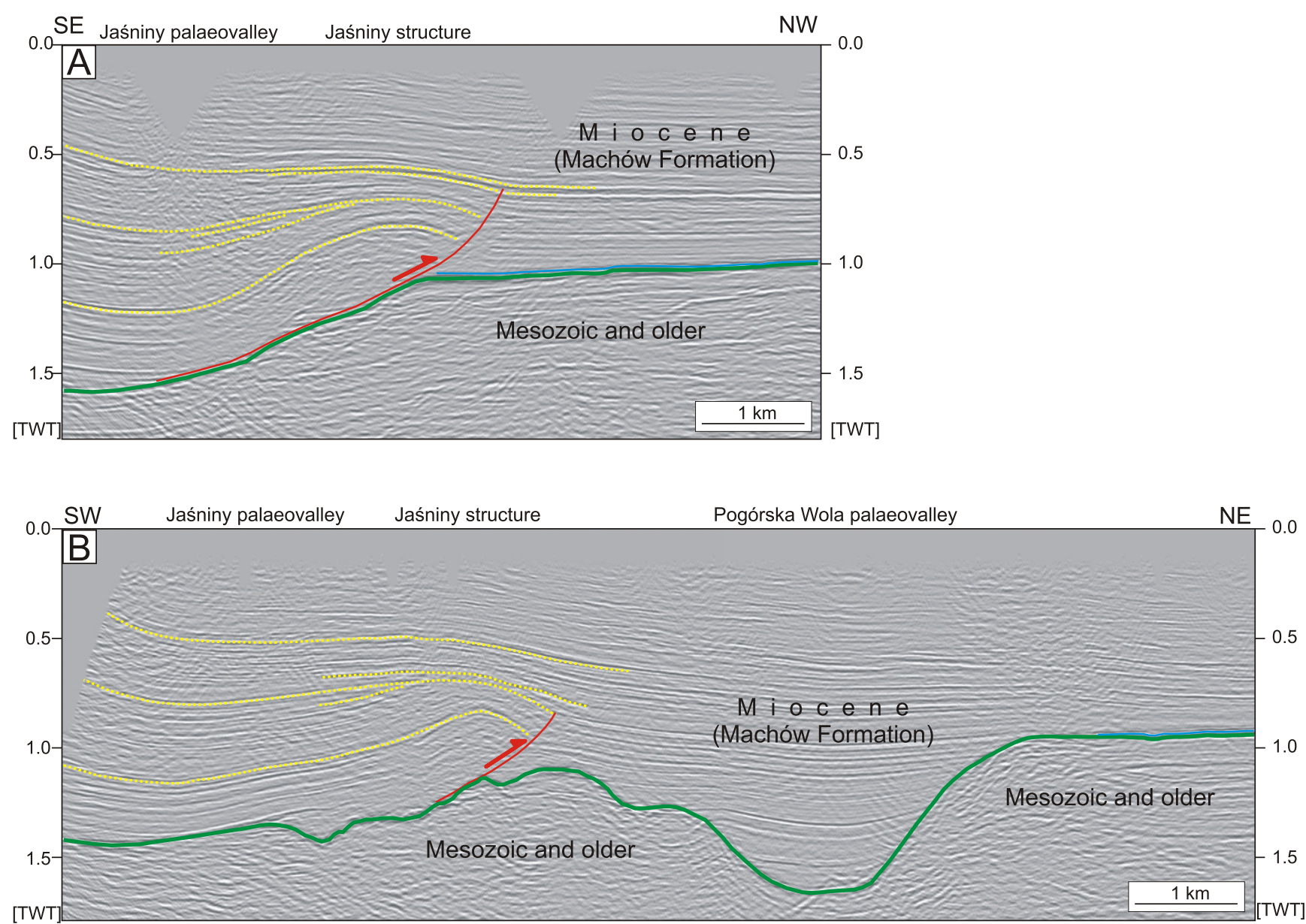

Fig. 9. Interpreted 2D seismic profiles showing the so-called Jaśniny structure (cf. Baran and Jawor, 1994) developed within the Miocene foredeep infill

Blue horizon - evaporites; vertical scale in TWT, approx. vertical depth exaggeration 3-4x; location see Figure 3; localized thinning of the Miocene strata within the hinge zone of this blind thrust and associated local intra-Miocene unconformities suggest syn-depositional thrusting within the Carpathian Foredeep Basin; the Jaśniny structure can be regarded as the buried northernmost frontal thrust of this segment of the Carpathian orogenic wedge

that is characterized by much smaller amounts of displacement and almost no growth strata. Profile D shows a very small thrust structure located further to the north than the Jaśniny structure; profile $E$ is characterized by the presence of two small (but slightly larger than those in profile D) thrusts. Such geometry may be attributed to lateral changes of morphology of the Meso-Paleozoic substratum that directly controlled the evolution of the frontal thrust of the Carpathian orogenic wedge (i.e. of the Jaśniny structure). Both profiles in Figure 9, and profiles A, B and to some degree also profile $C$ in Figure 10 , are located where the front of the orogenic wedge is relatively close to the steep northern slope of the Jaśniny palaeovalley. Such a relationship resulted in a significant buttressing effect that caused the formation of a large-scale syndepositional thrust (i.e. the Jaśniny structure). Profile $D$ is located where the Jaśniny palaeovalley and Pogórska Wola palaeovalley merge together and locally form a large flat area (Fig. 5); therefore, the buttressing effect was negligible and therefore a frontal ramp, formed in the vicinity of the northern slope of the distant Pogórska Wola palaeovalley, is characterized by a relatively small displacement (cf. Fig. 5). Profile $E$ is located where the northern slope of the Pogórska Wola palaeovalley is located already a little closer to the Carpathian thrust front and this is why one can observe there a slightly larger frontal thrust. Additionally, this profile also shows a second thrust detached above the evaporites and located within the frontal homocline of the triangle zone developed in the contact zone between the Skole thrust sheet and the foredeep basin (see below).

The interpreted seismic profiles were compared with the results of numerical modelling of syn-depositional fault-propagation folds (Hardy et al., 1996). The preservation of most of the growth strata and lack of, or only minor, localized erosion within the fold hinge suggest that the buried thrust front of the Carpathians between Tarnów and Pilzno evolved with a rate of uplift driven by thrusting equal to, or lower than, the sediment accumulation rates so that the accommodation space within the hinge zone of such a syndepositional fold has been largely preserved.

The "Pogórska Wola" 3D seismic survey also provided new detailed information on the structure of the zone located between the frontal Outer Carpathian thrust sheet (the Skole thrust sheet) and the Carpathian Foredeep Basin (i.e. the Zgłobice thrust sheet). The seismic profiles A-E show a triangle zone cored by deformed Upper Badenian foredeep evaporites, at the northern tip of which the most frontal thrust structure of the entire thrust belt (i.e. the Jaśniny structure) is located. The frontal homocline of this triangle zone (cf. Jones, 1996) developed above the backthrust along which supra-evaporitic Upper Badenian-Sarmation foredeep infill has been thrust towards the south, above the Skole thrust sheet that is unconformably covered by the Miocene infill of the Pilzno embayment (Fig. 10). 

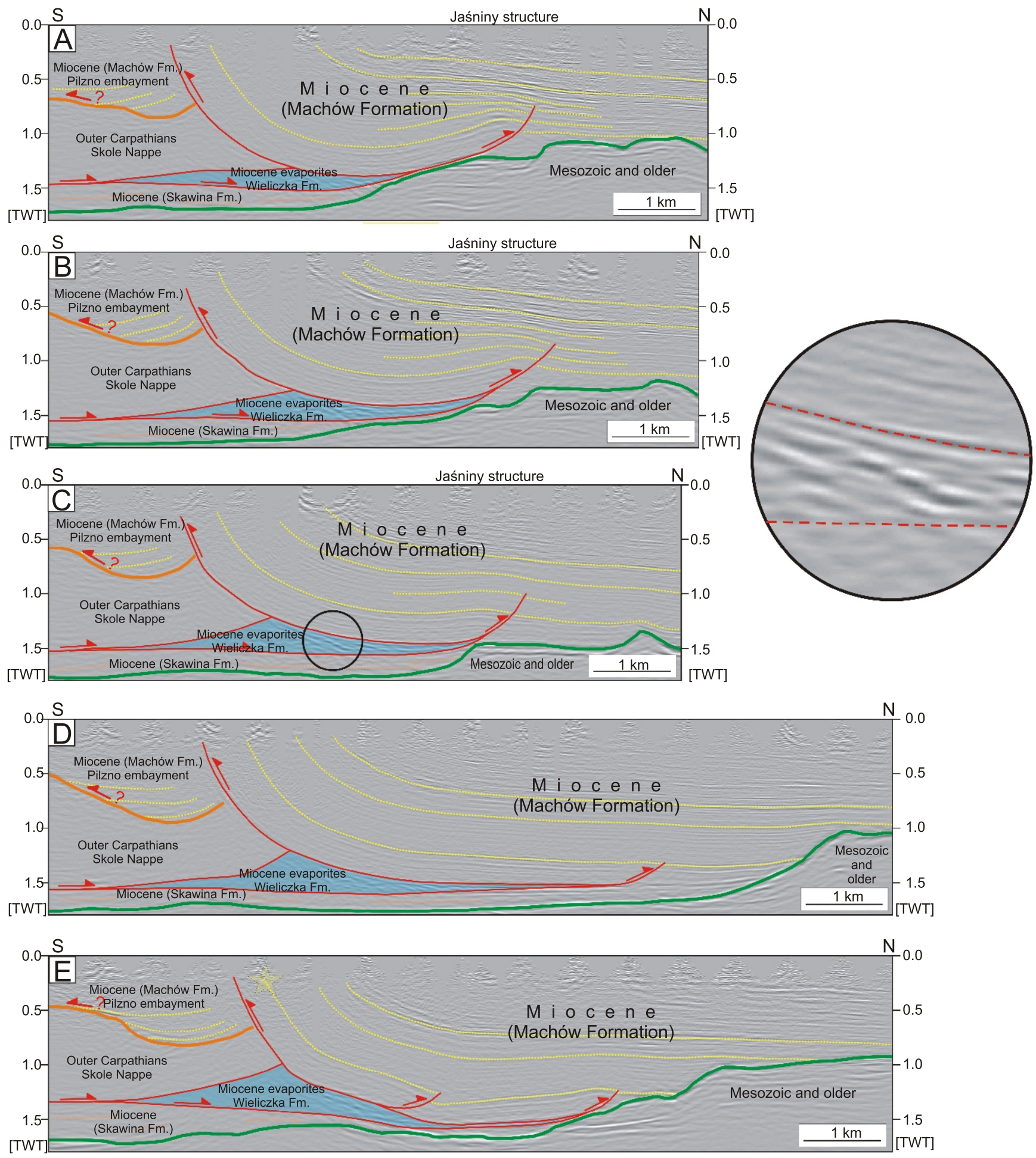

Fig. 10. Interpreted profiles from the 3D survey showing the structure of the Pilzno embayment filled by the Miocene foredeep strata the triangle zone developed in front of the Skole thrust sheet of the Outer Carpathians and filled by the highly deformed Miocene evaporites (blue colour), and blind thrust front developed within the Miocene foredeep infill

Vertical scale in TWT; approx. vertical depth exaggeration 3-4x; for location see Figure 3; star indicates approximate location of the Pilzno P-7 borehole, projected onto this seismic profile from the east along the backthrust (cf. Fig. 3); inset - details of the deformed evaporites located within the northern tip of the triangle zone imaged on seismic profile C, comparable to the deformed evaporites of the Wieliczka Salt Mine (cf. Krzywiec and Vergés, 2007: fig. 10) 
The unconformity at the base of the Pilzno embayment infill could be either tectonic and perhaps related to the southernmost segment of the backthrust (before it was breached during the latest tectonic movements along the backthrust), or it could be depositional. This problem is discussed in more detail below.

\section{MIOCENE EVOLUTION OF THE CARPATHIAN OROGENIC FRONT BETWEEN TARNÓW AND PILZNO - A MODEL}

The segment of the frontal Carpathian orogenic wedge analysed has been previously studied using subsurface and surface data. With one exception, all the previously published models proposed classical foreland-directed thrusting that propagated from the hinterland towards the foreland, i.e. from the Outer Carpathian flysch thrust sheets into the Miocene Carpathian Foredeep Basin (e.g., Połtowicz, 1974, 1991, 2004; Wdowiarz, 1976). Jurkiewicz and Woiński (1979) published a cross-section located in the vicinity of Dębica, i.e. ca. $10 \mathrm{~km}$ to the east of the area described in this paper (cf. Fig. 3). Part of this cross-section is shown in Figure 11. One can observe there a supra-evaporitic Miocene cover thrust towards the south above an inferred backthrust that, together with the frontal thrust of the Skole thrust sheet, define a triangle zone similar to the triangle zone proposed for the Pogórska Wola area (cf. Fig. 10). Geological maps from the second half of the 20th century were based on a large amount of surface geological data that is presently mostly unavailable due to increased anthropogenic surface infrastructure. Therefore, the geometry of the supra-evaporitic foredeep succession, concordantly uplifted towards the surface along the presumed backthrust developed in front of the Skole thrust sheet shown by Jurkiewicz and Woiński (1979) on their cross-section (Fig. 11), should be regarded as reliable.

Results of the interpretation of seismic data are supported by steep dips, up to $70^{\circ}$ (Fig. 6), of the Miocene supra-evaporitic cover drilled by the Pilzno P-7 borehole, located above the backthrust, within the frontal homocline dipping to the north (cf. Fig. 10).

The Jaśniny thrust structure identified on seismic data (Figs. 9 and 10) may be regarded as equivalent to the so-called
Biadoliny slice of the Zgłobice thrust sheet located in the area between Wojnicz and Brzesko and developed above the northern slope of the Szczurowa palaeovalley (Krzywiec, 2001; Krzywiec et al., 2004; Nemčok et al., 2006; Krzywiec and Vergés, 2007). Both features are the most frontal syndepositional thrust structures of the Carpathian orogenic wedge, developed within the supra-evaporitic (uppermost Badenian-Sarmatian) succession of the Carpathian Foredeep.

The frontal part of the Carpathian orogenic wedge in the Pogórska Wola area is characterized by the presence of a triangle zone with deformed Upper Badenian evaporites (Wieliczka Formation) in its core (cf. Fig. 2). This triangle zone developed during the final thrusting movements of the Carpathians after $12 \mathrm{Ma}$, as shown by the age (NN7 calcareous nannoplankton zones, see Fig. 2) of the youngest Miocene strata involved in backthrusting and penetrated by the Pilzno P-7 borehole. Figure 12 shows a conceptual qualitative model of the frontal Carpathian orogenic wedge and adjacent Carpathian Foredeep Basin prior to formation of the triangle zone. At that stage the frontal thrust of the Jaśniny structure, detached at the base of the foredeep evaporites, was already active. Development of this structure was facilitated by the presence of the mechanically weak foredeep evaporites, and by the buttressing effect exerted by relatively steep slope of the palaeovalley incised into the Meso-Paleozoic foreland plate. The Jaśniny fault-propagation fold was active as a syndepositional structure, as documented by growth strata and localized progressive unconformities developed within the crest of that fold. During continued propagation of the thrust belt, foreland-directed thrusting might have been blocked due to increased friction related to lateral facies and/or thickness changes of the evaporitic succession that served as a detachment level for this thrust system. Such lateral facies and/or thickness changes of the evaporites should be considered as a very probable scenario within the deeply incised palaeovalleys. Such blocking of the foreland-directed thrust movements might have resulted in formation of the backthrust, along which the entire supra-evaporitic Miocene foredeep cover has been thrust towards the south, towards and partly above the main Carpathian wedge. Most probably, initiation of the backthrust was also related to increased sediment loading within the foredeep basin, as shown by analogue modelling (Sieniawska et al., 2010).

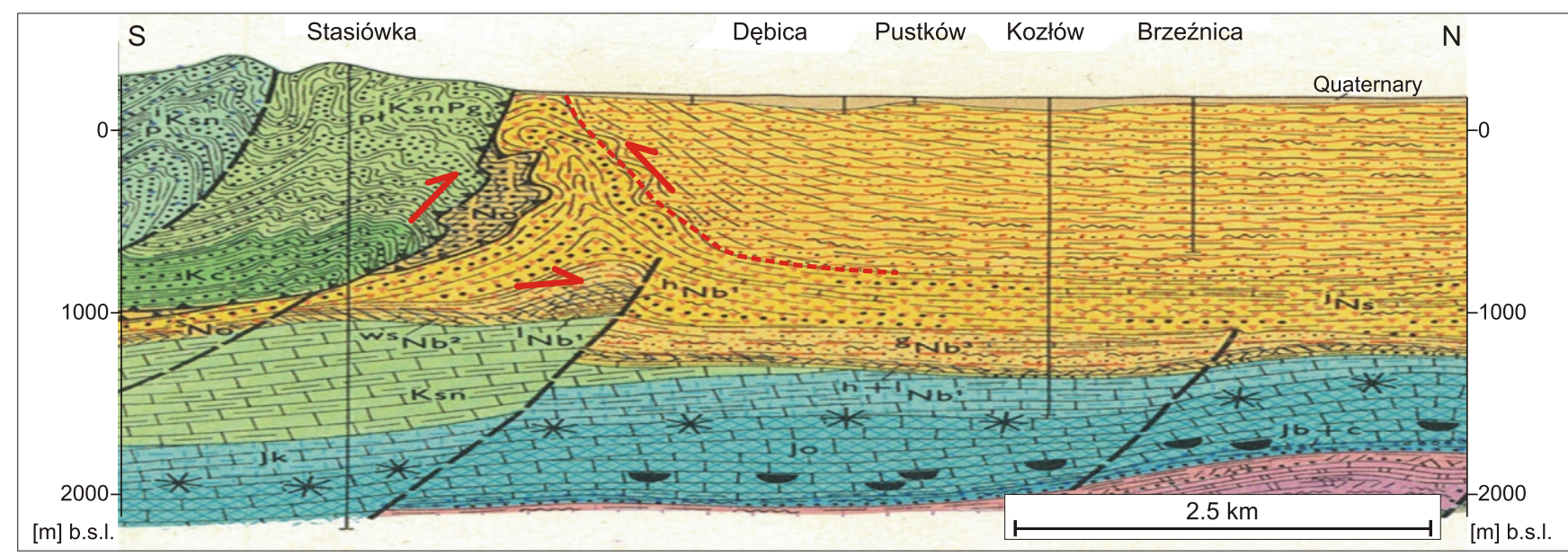

Fig. 11. Geological cross-section by Jurkiewicz and Woiński (1979) showing inferred triangle zone and backthrust developed within the Miocene infill of the Carpathian Foredeep Basin in front of the Outer Carpathian flysch thrust sheets

Yellow colours - Miocene infill of the Carpathian Foredeep, green colours - Cretaceous, blue colours - Jurassic, pink colours - Triassic; for other explanations see Jurkiewicz and Woiński (1979) 


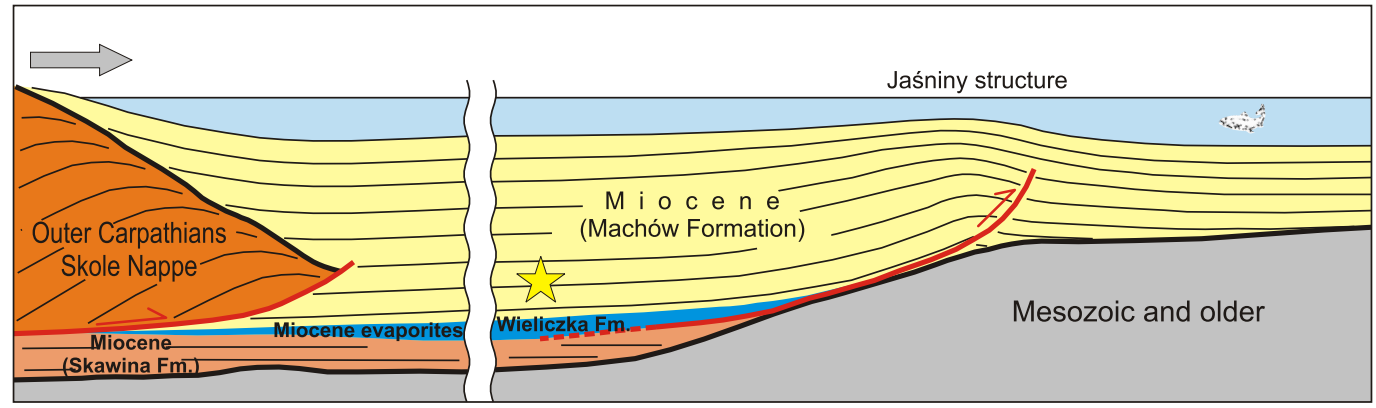

Fig. 12. Qualitative (not to scale) model for the Pogórska Wola area prior to formation of the triangle zone shown in Figure 10

General direction of sediment supply to the foredeep basin is from the south, from the eroded Carpathians, and is indicated by an arrow; yellow star - conceptual location of the section drilled by the Pilzno P-7 borehole; it should be remembered that during later phases of development of the foredeep basin further subsidence and deposition took place that resulted in even further burial of the deposits drilled by this borehole; the section of the foredeep infill drilled by the Pilzno P-7 borehole was uplifted due to backthrusting and formation of the triangle zone within the frontal part of the Carpathian orogenic wedge

The core of the triangle zone formed during backthrusting is filled by tectonically overthickened and strongly deformed evaporites (cf. inset on Fig. 10). Previous interpretation of thick and chaotic/deformed evaporites encountered by several boreholes drilled in that area was different - they were regarded as olistostromes i.e. synsedimentary features formed within the evaporitic basin, prior to any significant tectonic movements (Poltowicz, 1963, 1999). The presence of such syndepositional or early post-depositional deformations of the foredeep evaporites cannot be excluded (cf. Kolasa and Ślączka, 1985) but results of interpretation of high-resolution seismic data strongly suggest that these evaporites have been strongly tectonically deformed and overthickened during the final phases of formation of the Carpathian orogenic belt. Such a scenario for formation of a strongly deformed evaporitic succession filling the core of the triangle zone has been also suggested for the Wieliczka area (Wieliczka Salt Mine; Krzywiec and Vergés, 2007) and for the Biadoliny area (Krzywiec et al., 2004).

A very similar mechanism for the formation of compressional, salt-related deformations has also been proposed for the orogenic front of the Pyrenees (Sans et al., 1996; Koyi and Sans, 2006). The Sanaüja Anticline, filled by the deformed salt of the Cardona Formation (Eocene) is located in the core of a triangle zone, defined by the backthrust developed within the gypsum of the Barbastro Formation (Eocene-Oligocene). Location of the triangle zone in the frontal Pyrenees was to a large degree controlled by lateral thickness and facies changes of the Cardona Formation, similarly to the lateral thickness and facies changes of evaporites of the Wieliczka Formation, related to pre-evaporitic morphology controlled by palaeovalleys, deeply incised into the Meso-Paleozoic foreland plate of the Carpathian orogenic belt.

During formation of the backthrust, the supra-evaporitic foredeep succession was thrust towards the south, towards the Carpathians. The Miocene infill of the Pilzno embayment (Fig. 10) might have formed as a depositional cover of the deformed Skole thrust sheet, as shown on a model in Figure 12. An alternative scenario would be that it was tectonically displaced on top of the Skole thrust sheet during early stages of backthrusting. Such a scenario is well-known from various orogenic belts (cf. Banks and Warburton, 1986; Couzens-Schultz et al., 2003). The presence of shallow tectonic deformations above the backthrust was also postulated for the Wojnicz area (Krzywiec et al., 2004: fig. 5). Yet another scenario that could be considered might be simply combination of both options de- scribed above: the Miocene cover of the Pilzno embayment might have been deposited above the Skole thrust sheet and later might have been tectonically displaced during backthrusting above the triangle zone.

Seismic profile E (Fig. 10) shows a shallow foreland-vergent thrust within the frontal homocline, above the triangle zone. Similar shallow secondary thrusting above the regional backthrust has been identified on seismic data acquired within the frontal part of the Canadian Rockies (Begin and Spratt, 2002) and was attributed to the latest tectonic movements of this orogenic belt, similarly to the scenario proposed in this paper for the frontal Carpathians in the Tarnów-Pilzno area.

Thermochronological studies of core from this borehole have shown that the presently shallowest part of the foredeep succession uplifted above the backthrust was originally buried to max. $2 \mathrm{~km}$, that is compatible with the general burial history scenario shown on the model in Figure 12

\section{CONCLUSIONS}

The main conclusions of the study of the Carpathian front in the Tarnów-Pilzno area, completed using 2D and 3D seismic data and core from the Pilzno P-7 borehole may be summarized as follows:

- the Jaśniny structure is regarded as the most external, frontal thrust of the entire Carpathian orogenic wedge; it evolved as a syn-depositional fault-propagation fold detached above the Upper Badenian evaporites; its formation was controlled by the presence of mechanically weak foredeep evaporites and by the morphology of the sub-Miocene Meso-Paleozoic foreland plate (Jaśniny and Pogórska Wola palaeovalleys);

- the frontal zone of the Carpathian orogenic wedge is characterized by significant backthrusting of the supraevaporitic (uppermost Badenian-Sarmatian) foredeep succession towards the south, and by the presence of a well-developed triangle zone that has strongly deformed Upper Badenian evaporites of the Wieliczka Formation in its core;

- the age of the foredeep deposits uplifted above the backthrust (NN7 nannoplankton zone) together with the geometry of the frontal orogenic zone precisely imaged on the seismic data suggest that the latest thrusting 
movements of the Carpathians in the Tarnów-Pilzno area took place at ca. 11-10 Ma;

- the results of thermochronological studies (AFT and $\mathrm{AHe}$ ) indicate that the lower part of the supra-evaporitic cover, drilled by the Pilzno P-7 borehole, was not buried more deeply than $1.5-2.0 \mathrm{~km}$, which is compatible with the reconstruction based on seismic data.

Acknowledgements. Interpretation of seismic data, and sedimentological and micropalaeontological analysis of core from the Pilzno P-7 borehole was completed as part of the research project 6 T12 $2005 \mathrm{C} / 06569$ funded jointly by PGNiG S.A. and the Ministry of Science and Higher Education. PGNiG S.A. is thanked for providing access to all the seismic data. Thermochronological studies were completed as a part of the project "Mechanisms of uplift and erosion in the Carpathian thrust wedge and foreland basin (TopoEurope - ThermoEurope)", jointly funded by the Ministry of Science and Higher Education and by the European Science Foundation. P. Marciniec (Polish Geological Institute-National Research Institute, Kraków) is thanked for his co-operation during completion of the Pilzno P-7 borehole. Helpful reviews by J. Vergés (CSIC, Barcelona) and P. Aleksandrowski (PGI-NRI, Wrocław) are also acknowledged, T. Peryt (Polish Geological Institute - National Research Institute, Warszawa) is thanked for very useful editorial corrections.

\section{REFERENCES}

Alexandrowicz, S.W., Garlicki, A., Rutkowski, J., 1982. Podstawowe jednostki litostratygraficzne miocenu zapadliska przedkarpackiego (in Polish). Kwartalnik Geologiczny, 26 (2): 470-471.

Andreucci, B., Castelluccio, A., Jankowski, L., Mazzoli, S., Szaniawski, R., Zattin, M., 2013. Burial and exhumation history of the Polish Outer Carpathians: discriminating the role of thrusting and post-thrusting extension. Tectonophysics, 608: 866-883.

Artoni, A., Casero, P., 1997. Sequential balancing of growth structures, the late Tertiary example from the central Apennines. Bulletin de la Societé Geologique de France, 168: 35-49.

Aubry, M.-P., 1984. Handbook of Cenozoic Calcareous Nannoplankton, Book 1: Ortholithae (Discoasters). Micropaleontology Press, American Museum of Natural History, New York.

Aubry, M.-P., 1988. Handbook of Cenozoic Calcareous Nannoplankton, Book 2: Ortholithae (Holochoccoliths, Ceratoliths and others). Micropaleontology Press, American Museum of Natural History, New York.

Aubry, M.-P., 1989. Handbook of Cenozoic Calcareous Nannoplankton, Book 3: Ortholithae (Pentaliths, and others) and Heliolithae (Fasciculiths, Sphenoliths and others). Micropaleontology Press, American Museum of Natural History, New York.

Aubry, M.-P., 1990. Handbook of Cenozoic Calcareous Nannoplankton, Book 4: Heliolithae (Helicoliths, Cribriliths, Lopadoliths and others). Micropaleontology Press, American Museum of Natural History, New York.

Aubry, M.-P., 1999. Handbook of Cenozoic Calcareous Nannoplankton, Book 5: Heliolithae (Zygolithus and Rhabdolithus). Micropaleontology Press, American Museum of Natural History, New York.

Banks, C.J., Warburton, J., 1986. "Passive-roof" duplex geometry in the frontal structures of the Kirthar and Sulaiman mountain belts, Pakistan. Journal of Structural Geology, 3: 229-238.

Baran, U., Jawor, E., 1994. The conditions of the natural gas accumulation in the Miocene formations and the prospecting perspectives in the Tarnów-Pilzno area (in Polish with English summary). Nafta-Gaz, 50: 133-143.

Bąbel, M., 1999. Facies and depositional environments of the Nida Gypsum deposits (Middle Miocene, Carpathian Foredeep, southern Poland). Geological Quarterly, 43 (4): 405-428.

Babel, M., 2004. Badenian evaporite basin of the northern Carpathian Foredeep as a drawdown salina basin. Acta Geologica Polonica, 54: 313-337.

Begin, N., Spratt, D., 2002. Role of transverse faulting in along-strike termination of Limestone Mountain Culmination, Rocky Mountain thrust-and-fold belt, Alberta, Canada. Journal of Structural Geology, 24: 689-707.

Bown, P.R., ed., 1998. Calcareous Nannofossil Biostratigraphy. British Micropalaeontological Society Series. Kluwer Academic Publishers, Cambridge.
Boyer, S.E., Elliott, D., 1982. Thrust systems. AAPG Bulletin, 66: $1196-1230$.

Bukowski, K., 2011. Badenian saline sedimentation between Rybnik and Dębica based on geochemical, isotopic and radiometric research (in Polish with English summary). Rozprawy, Monografie Akademii Górniczo-Hutniczej w Krakowie, 236.

Bukowski, K., de Leeuw, A., Gonera, M., Kuiper, K.F., Krzywiec, P., Peryt, D., 2010. Badenian tuffite levels within the Carpathian orogenic front (Gdów-Bochnia area, Southern Poland): radio-isotopic dating and stratigraphic position. Geological Quarterly, 54 (4): 449-464.

Carlson, W.D., Donelick, R.A., Ketcham, R.A., 1999. Variability of apatite fission-track annealing kinetics: I. Experimental results. American Mineralogist, 84: 1213-1223.

Cisek, B., Czernicki, J., 1965. Rock salt occurrence in the Pilzno region (in Polish with English summary). Przegląd Geologiczny, 13: 351-353.

Ćorić, S., Švábenická, L., 2004. Calcareous nannofossil biostratigraphy of the Grund Formation (Molasse Basin, Lower Austria). Geologica Carpathica, 55: 147-155.

Couzens-Schultz, B.A., Vendeville, B.C., Wiltschko, D.V., 2003. Duplex style and triangle zone formation: insight from physical modelling. Journal of Structural Geology, 25: 1623-1644.

d’Obyrn, K., Przybyło, J., 2010. Rozpoznanie geologiczne złoża soli kamiennej „Wieliczka” do 1945 roku (in Polish). Przegląd Górniczy, 3-4: 110-121.

Donelick, R.A., O'Sullivan, P.B., Ketcham, R.A., 2005. Apatite fission-track analysis. Reviews in Mineralogy and Geochemistry, 58: 49-94.

DunkI, I., 2002. TRACKKEY: a Windows program for calculation and graphical presentation of fission track data. Computers and Geosciences, 28: 3-12.

Dune, W.M., Ferril, D.A., 1988. Blind thrust systems. Geology, 16: 33-36.

Farley, K.A., 2000. Helium diffusion from apatite: general behavior as illustrated by Durango fluorapatite. Journal of Geophysical Research, 105: 2903-2914.

Farley, K.A., Wolf, R.A., Silver, L.T., 1996. The effects of long alpha-stopping distances on (U-Th)/He dates. Geochimica et Cosmochimica Acta, 60: 4223-4230.

Ford, M., Williams, E.A., Artoni, A., Vergés, J., Hardy, S., 1997. Progressive evolution of a fault-related fold pair from growth strata geometries, Sant Llorenc de Morunys, SE Pyrenees. Journal of Structural Geology, 19: 413-441.

Fornaciari, E., Rio, D., 1996. Latest Oligocene to Early Middle Miocene quantitative calcareous nannofossil biostratigraphy in the Mediterranean region. Micropaleontology, 42: 1-37.

Garlicki, A., 1979. Sedimentation of Miocene salts in Poland (in Polish with English summary). Prace Geologiczne, 119: 1-66. 
Gągała, Ł., Vergés, J., Saura, E., Malata, T., Ringenbach, J-C., Werner, P., Krzywiec, P., 2012. Architecture and orogenic evolution of the northeastern Outer Carpathians from cross-section balancing and forward modeling. Tectonophysics, 532-535: 223-241.

Gierat-Nawrocka, D., ed., 1968. Poszukiwania złoża soli kamiennej w rejonie Tarnów-Pilzno-Dębica. Polish Geological Institute, Branch in Kraków (unpublished report No 1676).

Gleadow, A.J.W., Lovering, J.F., 1977. Geometry factor for external detectors in fission track dating. Nuclear Track Detection, 1: 99-106.

Gonera, M., 1994. Palaeoecology of marine Middle Miocene (Badenian) in the Polish Carpathians (Central Paratethys). Foraminifera record. Bulletin of the Polish Academy of Sciences, Earth Sciences, 42: 107-125.

Górecki, W., ed., 2011. Atlas of geothermal waters and energy resources in the Western Carpathians. Ministry of Environment, Kraków.

Hardy, S., Poblet, J., McClay, K., Waltham, D., 1996. Mathematical modelling of growth strata associated with fault-related fold structures. Geological Society Special Publications, 99: 265-282.

Hrdina, J.N., Hrdina, L.E., 1842. Geschichte der Wieliczkaer Saline. Carl Gerold, Wien.

Hurford, A.J., Green, P.F., 1983. The zeta age calibration of fission-track dating. Chemical Geology, 41: 285-317

Jasionowski, M., Peryt, T.M., 2010. Isotopic composition of dolomite associated with Middle Miocene Badenian anhydrites in the Carpathian Foredeep Basin of SE Poland. Geological Quarterly, 54 (4): 533-548.

Jones, P., 1996. Triangle zone geometry, terminology and kinematics. Bulletin of Canadian Petroleum Geology, 44: 139-152.

Jones, P., 1997. The Carpathians of the southern Poland: thrust tectonics or wedge tectonics (abs.): 1997 AAPG International Conference and Exhibition, Austria, Vienna, Abstract book: A27-A28.

Jurkiewicz, H., Woiński, J., 1979. Mielec. Geological Map of Poland, scale 1:200 000. Państwowy Instytut Geologiczny, Warszawa.

Karnkowski, P., 1978. Miocene paleodelta of the Carpathian foreland (in Polish with English summary). Przegląd Geologiczny, 26: 625-629.

Karnkowski, P., 1989. Deltaic deposits of the Carpathian foreland (in Polish with English summary). Przeglad Geologiczny, 37: 28-32.

Karnkowski, P.H., Ozimkowski, W., 2001. Structural evolution of the pre-Miocene basement in the Carpathian Foredeep (Kraków-Przemyśl region, SE Poland) (in Polish with English summary). Przegląd Geologiczny, 49: 431-436.

Karpała, A., Łapinkiewicz, A., 1962. Kilka uwag o interpretacj materiałów sejsmicznych w części środkowej i zachodniej przedgórza Karpat. Geofizyka Poszukiwawcza i Wiertnicza, 8-10: 3-16.

Kasprzyk, A., 1993. Lithofacies and sedimentation of the Badenian (middle Miocene) gypsum in the northern part of the Carpathian Foredeep, southern Poland. Annales Societatis Geologorum Poloniae, 63: 33-84

Kasprzyk, A., 1999. Sedimentary evolution of Badenian (Middle Miocene) gypsum deposits in the northern Carpathian Foredeep. Geological Quarterly, 43 (4): 449-465.

Kasprzyk, A., Ortí, F., 1998. Paleogeographic and burial controls on anhydrite genesis: the Badenian basin in the Carpathian Foredeep (southern Poland, western Ukraine). Sedimentology, 45: 889-907.

Kolasa, K., Ślączka, A., 1985. Sedimentary salt megabreccias exposed in the Wieliczka mine, Fore-Carpathian Depression. Acta Geologica Polonica, 35: 221-230.

Kotlarczyk, J., 1985. An outline of the stratigraphy of Marginal Tectonic Units of the Carpathian Orogene in the Rzeszów-Przemyśl area, In: Geotraverse Kraków-Baranów-Rzeszów-Przemyśl-Komańcza-Dukla (ed. J. Kotlarczyk): 21-32. Guide to excursion 4. XIII Congr. Carpath.-Balkan Geol. Ass., Kraków, Poland.

Kováč, M., Nagymarosy, A., Oszczypko, N., Ślączka, A., Csontos, L., Marunteanu, M., Matenco, L., Marton, E., 1998. Palinspastic reconstruction of the Carpathian-Pannonian region during the Miocene. In: Geodynamic Development of the
Western Carpathians: Bratislava (ed. M. Rakus): 189-217. Slovak Geological Survey.

Koyi, H., Sans, M., 2006. Deformation transfer in viscous detachments: comparison of sandbox models to the South Pyrenean Triangle Zone. Geological Society Special Publications, 253: 117-134.

Krzywiec, P., 2001. Contrasting tectonic and sedimentary history of the central and eastern parts of the Polish Carpathian Foredeep Basin - results of seismic data interpretation. Marine and Petroleum Geology, 18: 13-38.

Krzywiec, P., 2009. Devonian-Cretaceous repeated subsidence and uplift along the Tornquist-Teisseyre Zone in SE Poland - insight from seismic data interpretation. Tectonophysics, 475: 142-159.

Krzywiec, P., Vergés, J., 2007. Role of the foredeep evaporites in wedge tectonics and formation of triangle zones: comparison of the Carpathian and Pyrenean Thrust Fronts. In: Thrust Belts and Foreland Basins - from Fold Kinematics to Petroleum Systems (eds. O. Lacombe, J. Lavé, F. Roure and J. Vergés): 383-394. New Frontiers in Earth Sciences, Springer.

Krzywiec, P., Aleksandrowski, P., Florek, R., Siupik, J., 2004. The structure of the Outer Carpathian orogenic front: an example of the Miocene Zgłobice unit between Brzesko and Wojnicz new data, new models, new questions (in Polish with English summary). Przeglad Geologiczny, 52: 1051-1059.

Krzywiec, P., Aleksandrowski, P., Ryzner-Siupik, B., Papiernik, B., Siupik, J., Mastalerz, K., Wysocka, A., Kasiński, J., 2005. Geological structure and origin of the Miocene Ryszkowa Wola Horst (Sieniawa-Rudka area, eastern part of the Carpathian Foredeep Basin) - results of 3D seismic data interpretation (in Polish with English summary). Przegląd Geologiczny, 53: 656-663.

Krzywiec, P., Gutowski, J., Walaszczyk, I., Wróbel, G., Wybraniec, S., 2009. Tectonostratigraphic model of the Late Cretaceous inversion along the Nowe Miasto-Zawichost fault zone, SE Mid-Polish Trough. Geological Quarterly, 53 (1): 27-48.

Krzywiec, P., Bukowski, K., Oszczypko, N., Garlicki, A., 2012 Structure and Miocene evolution of the Gdów tectonic "embayment" (Polish Carpathian Foredeep) - new model based on reinterpreted seismic data. Geological Quarterly, 56 (4): 907-920.

Majorowicz, J., Wybraniec, S., 2011. New terrestrial heat flow map of Europe after regional paleoclimatic correction application. International Journal of Earth Sciences, 100: 881-887.

Martini, E., 1971. Standard Tertiary and Quaternary calcareous nannoplankton zonation, II. Proc. II Planktonic Conf. Roma 1970. Edizioni Tecnoscienza, Rome: 729-785.

Martini, E., Worsley, T., 1970. Standard Neogene calcareous nannoplankton zonation. Nature, 225: 289-290.

Mazzoli, S., Jankowski, L., Szaniawski, R., Zattin, M., 2010 Low-T thermochronometric evidence for post-thrusting ( $<11 \mathrm{Ma}$ ) exhumation in the Western Outer Carpathians, Poland. Comptes Rendus Geoscience, 342: 162-169.

Medwedeff, D.A., 1989. Growth fault-bend folding at southeast Lost Hill, San Joaquin Valley, California. AAPG Bulletin, 73: 54-67.

Meesters, A.G.C.A., Dunai, T.J., 2005. A noniterative solution of the $(\mathrm{U}-\mathrm{Th}) / \mathrm{He}$ age equation. Geochemistry Geophysics Geosystems, 6.

Morley, C.K., 1986. A classification of thrust fronts. AAPG Bulletin, 70: 12-25.

Moryc, W., 1995. Terrestrial Palaeogene formations of in the area of Carpathian Foredeep (in Polish with English summary). NaftaGaz, 61: 181-195.

Nemčok, M., Krzywiec, P., Wojtaszek, M., Ludhová, L., Klecker, R.A., Sercombe, W.J., Coward, M.P., 2006. Tertiary development of the Polish and eastern Slovak parts of the Carpathian accretionary wedge: insights from balanced cross sections. Geologica Carpathica: 57, 355-370.

Ney, R., Burzewski, W., Bachleda, T., Górecki, W., Jakóbczak, K., Słupczyński, K., 1974. Outline of paleogeography and evolution of lithology and facies of Miocene layers in the Carpathian Foredeep (in Polish with English summary). Prace Geologiczne, 82.

Niedźwiedzki, J., 1883-1886. Stosunki geologiczne formacyi solonośnej Wieliczki i Bochni. Kosmos, 8 (1883): 137-159, 387-401, 483-492; 9 (1884): 565-580, 717-743; 11 (1886): 137-155. 
Ochał, J., Borowska, L., 1995. Opracowanie wyników badań sejsmicznych, temat: Pogórska Wola 3D. Central Geological Archive, Warsaw (unpublished report No 2671/96).

Ori, G.G., Roveri, M., Vannoni, F., 1986. Plio-Pleistocene sedimentation in the Apenninic - Adriatic foredeep (Central Adriatic Sea, Italy). IAS Special Publication, 8: 183-198.

Oszczypko, N., 1997. The Early-Middle Miocene Carpathian peripheral foreland basin (Western Carpathians, Poland). Przegląd Geologiczny, 45: 1054-1063.

Oszczypko, N., 1998. The Western Carpathian foredeep-development of the foreland basin in front of the accretionary wedge and its burial history (Poland). Geologica Carpathica., 49: 1-18.

Oszczypko, N., 1999. The Miocene subsidence of the Polish Carpathian Foredeep (in Polish with English summary). Prace Państwowego Instytutu Geologicznego, 168: 209-230.

Oszczypko, N., Oszczypko-Clowes, M., 2012. Stages of development in the Polish Carpathian Foredeep Basin. Central European Journal of Geosciences, 4: 138-162.

Oszczypko, N., Olszewska, B., Ślęzak, J., Strzępka, J., 1992. Miocene marine and brackish deposits of the Nowy Sącz basin (Polish Western Carpathians) - new lithostratigraphic and biostratigraphic standards. Bulletin of the Polish Academy of Sciences, Earth Sciences, 40: 83-96.

Oszczypko, N., Krzywiec, P., Popadyuk, I., Peryt, T., 2006. Carpathian Foredeep Basin (Poland and Ukraine) - its sedimentary, structural and geodynamic evolution. AAPG Memoir, 84: 293-350.

Oszczypko-Clowes, M., Oszczypko, N., Wójcik, A., 2009. New data on the late Badenian-Sarmatian deposits of the Nowy Sącz Basin (Magura Nappe, Polish Outer Carpathians) and their palaeogeographical implications. Geological Quarterly, $\mathbf{5 3}$ (3) 273-292.

Perch-Nielsen, K., 1985. Cenozoic calcareous nannofossils. In: Plankton Stratigraphy (eds. H.M. Bolli, J.B. Saunders and K. Perch-Nielsen): 427-554. Cambridge Univ. Press, Cambridge.

Peryt, T.M., 1996. Sedimentology of Badenian (middle Miocene) gypsum in eastern Galicia, Podolia and Bukovina (West Ukraine). Sedimentology, 43: 571-588.

Peryt, T.M., 2001. Gypsum facies transitions in basin-marginal evaporites: middle Miocene (Badenian) of West Ukraine. Sedimentology, 48: 1103-1119.

Peryt, T.M., 2006. The beginning, development and termination of the Middle Miocene Badenian salinity crisis in Central Paratethys. Sedimentary Geology, 188-189: 379-396.

Peryt, T.M., Hałas, S., Karoli, S., Peryt, D., 1997. Isotopic record of environmental changes during deposition of Badenian (Middle Miocene) gypsum at Kobeřice near Opava (Czech Republic) (in Polish with English summary). Przegląd Geologiczny, 45: 807-811.

Peryt, T.M., Peryt, D., Szaran, J., Hałas, S., Jasionowski, M., 1998. Middle Miocene Badenian anhydrite horizon in the Ryszkowa Wola 7 borehole (southeast Poland) (in Polish with English summary). Biuletyn Państwowego Instytutu Geologicznego, 379: $61-78$

Poborski, J., 1965. Historical development of views on the geological structure of the salt beds of Wieliczka (in Polish with English summary). Studia i materiały do dziejów żup solnych w Polsce, 1: $37-54$.

Poltowicz, S., 1963. Salt-bearing formations in the bore-hole Pogórska Wola near Tarnów (in Polish with English summary). Kwartalnik Geologiczny, 7 (3): 431-438.

Połtowicz, S., 1964. Przedtortońska dolina rzeczna między Rabą i Dunajcem. Geofizyka i Geologia Naftowa, 6-7: 176-181.

Połtowicz, S., 1974. Tectonic structure of the Carpathian border in the Tarnów and Pilzno area (Polish Middle Carpathians) (in Polish with English summary). Annales Societatis Geologorum Poloniae, 44: 491-514

Poltowicz, S., 1991. Miocene of the Carpathian Zone between Wieliczka and Dębica (in Polish with English summary). Kwartalnik AGH Geologia, 17: 19-57.

Połtowicz, S., 1993. Palinspastyczna rekonstrukcja paleogeografii badeńskiego salinarnego zbiornika sedymentacyjnego w Polsce. Kwartalnik Geologia AGH, 19: 203-233.

Połtowicz, S., 1998a. The Lower Sarmatian delta of Szczurowa on the background of the Carpathian Foreland geological evolution (in Polish with English summary). Kwartalnik Geologia AGH, 24: 219-239.
Połtowicz, S., 1998b. Middle-Badenian submarine erosion in Carpathian Foreland. Exploratory implications (in Polish with English summary). Nafta-Gaz, 54: 209-215.

Połtowicz, S., 1999. Badenian olisthostromes and turbidity fans near Tarnów (Middle Carpathian Foreland) (in Polish with English summary). Kwartalnik AGH Geologia, 25: 153-187.

Połtowicz, S., 2004. The Stebnik and Zgłobice Units in the Polish Carpathians structure (in Polish with English summary). Kwartalnik AGH Geologia, 30: 85-120.

Poltowicz, S., Starczewska-Popow, A., 1973. The development of the Carpathian Foredeep between Tarnów and Przemyśl, Polish eastern Carpathians. Annales Societatis Geologorum Poloniae 43: 495-517.

Poprawa, P., Pelczarski, A., Szewczyk, J., 2002. Post-orogenic uplift and erosion of the Polish Carpathian Foredeep - constraints from compaction analysis. Geologica Carpathica, 53, Spec. Issue, XVII Congress of Carpathian-Balkan Geol. Assoc., Bratislava, Proceedings. (not paginated).

Pusch, G.G., 1824. Geognostisch-bergmännische Reise durch einen Theil der Karpathen, Ober- und Nieder-Ungarn ausgestellt im Jahre 1821. Johann Ambrosius Barth, Leipzig.

Richter-Bernburg, G., 1955. Über salinare Sedimentation. Zeitschrift der Deutschen Geologischen Gesellschaft, 105: 593-645.

Roth, P.H., Thierstein, H., 1972. Calcareous nannoplankton: Leg 14 of the Deep Sea Drilling Project. Initial Reports DSDP, 14: 421-485.

Sans, M., Muňoz, J.A., Vergés, J., 1996. Triangle zone and thrust wedge geometries related to evaporitic horizons (southern Pyrenees). Bulletin of Canadian Petroleum Geology, 44: 375-384.

Scheck-Wenderoth, M., Krzywiec, P., Zülke, R., Maystrenko, Y. Frizheim, N., 2008. Permian to Cretaceous tectonics. Georg Christian Grund, Hamburg, 2: 999-1030.

Schober, C.G., 1750. Physikalische Nachricht von den pohlnischen Salzgruben Wieliczka und Bochnia. Hamburgisches Magazin, 16: 115-155.

Sieniawska, I., Aleksandrowski, P., Rauch, M., Koyi, H., 2010. Control of synorogenic sedimentation on back and out of sequence thrusting: Insights from analog modeling of an orogenic front (Outer Carpathians, southern Poland). Tectonics, 29: TC6012, doi: 10.1029/2009TC002623

Sinclair, H.D., 1997. Tectonostratigraphic model for underfilled peripheral foreland basins: an Alpine perspective. GSA Bulletin, 109: 324-346.

Suppe, J., Chou, G.T., Hook, S.C., 1992. Rates of folding and faulting determined from growth strata. In: Thrust Tectonics (ed. K.R. McClay): 105-121. Chapman and Hall.

Ślączka, A., Kruglov, S., Golonka, J., Oszczypko, N., Popadyuk, I., 2006. Geology and hydrocarbon resources of the Outer Carpathians, Poland, Slovakia, and Ukraine. General Geology. AAPG Memoir, 84: 221-258.

Środoń, J., 1984. Mixed-layer illite/smectite In low temperature diagenesis: data from the Miocene of the Carpathian Foredeep. Clays and Clay Minerals, 19: 205-215.

Švábenická, L., 2002. Calcareous nannofossils of the Upper Karpatian and Lower Badenian deposits in the Carpathian Foredeep, Moravia (Czech Republic). Geologica Carpathica, 53: 197-210.

Townson, R., 1797. Travels in Hungary with a short account of $\mathrm{Vi-}$ enna in the year 1793. G.G. and J. Robinson, London.

Uhlig, V., 1903. Bau und Bild der Karpaten. V. Tempsky und G. Freytag, Wien und Leipzig.

Wdowiarz, S., 1976. On the relation of the Carpathians to the Carpathian foredeep in Poland (in Polish with English summary). Przegląd Geologiczny, 24: 350-357.

Wolf, R.A., Farley, K.A., Silver, L.T., 1996. Helium diffusion and low-temperature thermochronometry of apatite. Geochimica et Cosmochimica Acta, 60: 4231-4240.

Young, Y., 1998. Neogene. In: Calcareous Nannofossil Biostratigraphy (ed. P.R. Bown): 225-265. Cambridge University Press, Cambridge.

Żytko, K., Zając, R., Gucik, S., Ryłko, W., Oszczypko, N., Garlicka, I., Nemčok, J., Eliáš, M., Menčik, Stránik, Z., 1989. Map of the tectonic elements of the Western Outer Carpathians and their foreland (1:500 000). Państwowy Instytut Geologiczny, Warszawa. 